Çukurova Üniversitesi Eğitim Fakültesi Dergisi

Vol: 50 Numb: 2 Page: 877-906

https://dergipark.org.tr/tr/pub/cuefd

\title{
The Effect of Writing To Learn Activities on Motivation Strategies Ayhan inciRCi ${ }^{*}$ (0000-0001-8566-6079) \\ Aslıhan KUYUMCU VARDAR ${ }^{b}$ (0000-0002-0533-7345)
}

${ }^{a}$ Ankara Yıldırım Beyazıt Üniversitesi, Rektörlük, Ankara / Türkiye

${ }^{b}$ Düzce Üniversitesi, Eğitim Bilimleri Enstitüsü, Düzce / Türkiye

CrossMark

\begin{tabular}{l} 
Article Info \\
\hline DOI: $10.14812 /$ cufej.867812 \\
\hline Article history: \\
Received $\quad 25.01 .21$ \\
Revised $\quad 19.03 .21$ \\
Accepted $\quad 08.09 .21$ \\
\hline Keywords: \\
Writing to learn, \\
Motivation strategies, \\
Test Anxiety.
\end{tabular}

\begin{abstract}
The aim of this study is to investigate the effect of Writing To Learn (WTL) activities on motivation strategies. For this purpose, a study group consisting of $9^{\text {th }}$ grade students was employed. The students participating in the research consisted of one control (n:30; 17 girls, 13 boys) and two experimental groups (EG1, n:31; 17 girls, 14 boys; EG2, n: 30; 16 girls, 14 boys). The research was conducted with a nonequivalent control group pretest-posttest design which is one of the quasi-experimental designs. The data of the study were collected using quantitative and qualitative data collection tools. Güdülenme Stratejileri Ölçeği (GSÖ) adapted to Turkish by Büyüköztürk, Akgün, Kahveci \& Demirel (2004) was used as the quantitative data collection tool. The qualitative data tool of the study was the interview protocol asked to sample group selected from the experimental group students ( $E G 1, n: 3 ; E G 2, n: 3$ ). In the light of the findings of the research, it was proved that WTL activities increase the motivation of the students. In addition, it was found that the feedback given along with WTL enabled students to be more motivated than the non-feedback given students. Based on the results of the research, it was suggested that WTL activities should be used to teach motivation strategies.
\end{abstract}

\begin{tabular}{|c|c|}
\hline Makale Bilgisi & Öz \\
\hline DOI: 10.14812/cufej.867812 & \multirow{6}{*}{ 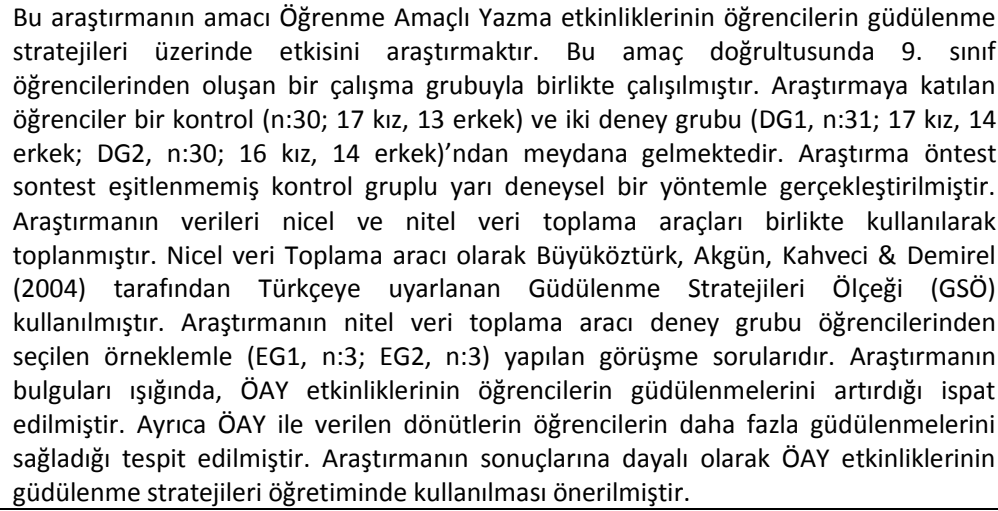 } \\
\hline Makale Geçmişi: & \\
\hline Geliş $\quad 25.01 .21$ & \\
\hline Düzeltme $\quad 19.03 .21$ & \\
\hline Kabul $\quad 08.09 .21$ & \\
\hline $\begin{array}{l}\text { Anahtar Kelimeler: } \\
\text { Öğrenme amaçlı yazma, } \\
\text { Güdülenme stratejileri, } \\
\text { Motivasyon stratejileri, } \\
\text { Sınav Kaygısı. }\end{array}$ & \\
\hline
\end{tabular}

\footnotetext{
* This article culled from the first author's PhD dissertation, which was supervised by Dr. Aslıhan Kuyumcu Vardar.

*Author: aincirci@ybu.edu.tr
} 


\section{Introduction}

Curricula are periodically updated worldwide in accordance with the needs of the age, field, and sector. With the changes in the curriculum, differentiation in learning approaches, methods, and techniques emerge (Caliskan and Çangal, 2013). The Ministry of National Education makes the changes to the curriculum in Turkey in accordance with the requirements of the age. The most recent of these changes is the change in the English course curriculum with many curricula in the 2017-2018 academic year. With renewed foreign language curricula, English teaching in Turkey begins with 2nd and continues to 12 th grade.

The approach based on the renewed programs is determined as a communicative approach (MEB, 2018a). When leveling the programs, The Common European Framework of Reference for Languages (CEFR) (CoE, 2011) was taken into account and the learning target of the primary English curriculum was determined as level A2. It is seen that there is a plan to start from the A1 level and continue to the A2 level. Although it was stated that all four skills in CEFR should progress at the same level at this level, four skills do not progress at the same level in English Curriculum in Turkey (MEB, 2018a; Distinguished, 2011; Paker, 2012). The programs focus on listening and speaking skills, while limited reading and writing skills are targeted (MEB, 2018a). Although this may seem like negativity, it is a positive situation and the reason is to underlie the communicative approach. With this approach, students' communication skills, especially speaking skills, are prioritized (Aliş, 2008; The Sun, 2011). Considering the age and developmental levels of the students, it can be stated that this situation is suitable for the natural language learning process. Because when individuals come into the world, they first acquire the skills of listening and speaking. They then learn the skills of reading and finally writing (Terrell, 1977; Krashen and Terrell, 1983; Cameron, 2001; Young, Hazarika, Poria and Cambria, 2018).

In addition to the factors that extrinsically affect learning, such as the curriculum, there are also important affective factors such as "motivation" that affect learning. Motivation can be defined as the learner's belief in learning. This definition in foreign language education is the belief that the learner can learn a foreign language. Motivation in foreign language learning and acquisition is a key concept. Although modeling in the field of motivation helps to gain an idea of the theoretical basis of motivation, teachers and researchers are still in the need of the applicable methods, techniques, and effectiveness that can be used in the classroom that increase motivation (Lasagabaster, Doiz and Sierra, 2014). Theoretically constructed research that has a direction from theory to practice is insufficient to fill the gap between the targeted motive and the resulting motive in the real class environment. Therefore, it is more useful to evolve research on motivation in a direction from practice to theory. In order to increase motivation for this purpose, more experimental studies are needed in the learning-teaching environment.

The aim of this research is to investigate the effect of WTL activities applied in English lessons on Motivation Strategies. For this purpose, answers to the following questions are sought:

1) When the pre-test scores of the students in the experimental and control groups obtained from the Motivational Scale (MS) are controlled, is there a statistically significant difference among the posttest scores?

2) What are the opinions of the Experimental Group students about the effect of WTL activities on Motivation Strategies?

\section{Method}

\section{Study Group}

The study group of the research consists of ninety-one $9^{\text {th }}$ grade students in a city in the west of the Black Sea Region in the 2018-2019 academic year. There are three different student sub-groups which are; Control Group (CG), Experimental Group 1 (EG1), and Experimental Group 2 (EG2) in the study group. Information on the study group is presented in Table 1. 
Table 1.

Information of the Study Group

\begin{tabular}{lllll}
\hline Group & Gender & $\mathrm{N}$ & Age & $\begin{array}{l}8^{\text {th }} \text { Grade English } \\
\text { GPA }\end{array}$ \\
\hline CG & Female & 16 & 13.50 & 71.25 \\
& Male & 14 & 13.29 & 70.36 \\
EG1 & Female & 17 & 13.41 & 62.94 \\
& Male & 14 & 13.14 & 66.07 \\
EG2 & Female & 17 & 13.23 & 67.06 \\
& Male & 13 & 13.61 & 63.46 \\
Total & Female & 50 & 13.38 & 67.08 \\
& Male & 41 & 13.35 & 66.63
\end{tabular}

When Table 1 is examined it is stated that; the total number of students participating in the study is 91 (Female, N:50; Male, N:41), CG is 30 (Female, N:16; Male, N:14), EG1 is 31 (Female, N:17; Male, $\mathrm{N}: 14$ ), EG2 is 30 (Female, N:17; Male, N:13). The average age of the students is 13.50 for girls and 13.29 for boys in CG; girls 13.41 and boys 13.14 in EG1; girls are 13.23, boys are 13.61 in EG2 and girls are 13.38 and boys were 13.35 at total. The grade point average of the students in the previous academic year was 71.25 for girls and 70.36 for boys in CG; girls 62.94 and boys 66.07in EG1; 67.06 for girls, 63.46 for boys in EG2; 67.08 for girls and 66.63 for boys total. It can be stated that the distribution of students by age and grade is almost equivalent.

\section{Data Tools}

\section{Motivated Strategies Scale}

The MSLQ was created by the National Center for Research to Improve Postsecondary Teaching and Learning from 1982 to 1986, coordinated by the University of Michigan in the United States. The original name of the scale is the Motivated Strategies for Learning Questionnaire (MSLQ). It was translated into Turkish as the Güdülenme ve Öğrenme Stratejileri Ölçeği (GÖSÖ) by ACGün, Kahveci and Demirel (2004). The Turkish form of the questionnaire was applied to 852 students (Female, N:600, 70.4\%; Male, N:208, $24,4 \%$ ) at two different universities. An explanatory and validating factor analyses were performed to examine the structure validities of the two main dimensions of the MLSQ, the Motivation Scale (MS) and the Learning Strategies Scale (LSS). It was determined that the questionnaire consisted of 81 substances, the MS consisted of a six-factor structure, and the LSS consisted of a nine-factor structure.

The scale is in a 7-type Likert form. Participants were able to participate in items; (1) they mark by stating a value between absolutely false for me and (7) absolutely true for me. A high score from any part, sub size, or subscale of the scale indicates that the value associated with the relevant unit is high, while the low score indicates that the value is low. In this research, the dimension of Motivation Strategies of the scale was used as a separate scale of the MS. Information about the motivation section is presented in Table 2.

\section{Table 2.}

Item Distribution of Motivation Subscale

\begin{tabular}{llll}
\hline Sub-Scale & Sub-Factor & $\mathbf{N}$ & Items \\
\hline \multirow{2}{*}{ Value } & Intrinsic Goal Orientation & 4 & $1,16,22,24$ \\
& Extrinsic Goal Orientation & 4 & $7,11,13,30$ \\
\multirow{3}{*}{ Expectancy } & Task Value & 6 & $4,10,17,23,26,27$ \\
& Self-Efficacy Perception & 8 & $5,6,12,15,20,21,29,31$ \\
Affection & Need for Learning & 4 & $2,9,18,25$ \\
\hline
\end{tabular}


The Motivation section in Table 2 consists of three sub-scales and six sub-factors. Sub-scales of the scale are; Value, Expectancy, and Affection. The value sub-scale consists of three sub-factors; Intrinsic Goal Orientation, Extrinsic Goal Orientation, Task Value. There are two sub-factors in the expectancy sub-scale; Self-Efficacy Perception and The Need for Learning Control. The Affective sub-scale consists of the Test Anxiety sub-factor. The motivation section consists of a total of 31 items. Items 3, 8, 14, 19, 28 are reverse articles.

\section{Interview questions}

Interview questions were developed by the researcher. Six branch teachers and two curriculum experts working in the Board of Education were consulted. The questions were prepared as three main questions under the heading of motivation strategies, which is the dependent variable of the research. After the interview questions were applied as a pilot study to three secondary school students, it was determined that all the questions worked efficiently. One week after the application of the experimental method, the $13^{\text {th }}$ week of the 2018-2019 academic year, interview questions were asked to six students (EG1, N:3; EG2, N:3) and their answers created the data for qualitative analysis.

\section{Data Analysis}

After the evaluation of the pretests, the analyses were carried out in two stages. First of all, quantitative data obtained from MS were analyzed. In the quantitative part; groups are ranked from high to low success based on their scores from tests. Then, a variance analysis test (ANOVA) was applied to determine whether the scores of the groups from the tests differed meaningfully. As a result of variance analysis, post hoc tests were applied to determine which score the groups differed in favor. After this analysis, Bonferroni was applied to the data which had homogeneous distribution, and the Tamhane post hoc test was applied to the non-homogeneous data so as to determine which groups made a difference. The most preferred parametric tests in post hoc tests are LSD and Bonferroni (Kayri, 2009). The LSD method applies standard t-tests to all possible group mean pairs. LSD testing is a posthoc statistic that is considered objectionable if the number of groups to determine the difference is more than 3 (Saville, 1990) because as the number of groups increases, the number of errors per group increases. Therefore, LSD multiple comparison statistics should not be used if the number of groups compared is large (Williams and Abdi, 2010). LSD testing is also mathematically highly vulnerable to type I error (Efe, et al., 2000). Therefore, the Bonferroni test is preferred. The Bonferroni test (also referred to as the Dunn procedure) is performed at a rigorous level of importance to ensure that the falsepositive rate does not exceed the specified value. It is a widely used multiple compariPost-test and does not require the principle of "equal number of samples" (Miller, 1977). The Tamhane test, which is used for homogeneous non-dispersing data, is considered more appropriate than Tukey's HSD in cases where cell sizes are unequal or the homogeneity of variances is violated. Tamhane's statistics are a test conducted only on the basis of "student $t$ ", and stand out for making conservative and careful comparisons (Hochberg and Tamhane, 1987).

Then, in the qualitative part, the data obtained from the interview were analyzed using the descriptive analysis approach. When analyzing interview questions, the dimension and sub-scales in the scale used in the quantitative dimension of the research were used as themes. In this way, quantitative and qualitative data of the research were collected under the same headings and a more holistic approach was obtained. Data from Interview Questions were evaluated using descriptive analysis with pre-determined themes. Themes reached by directly quoting student opinions were supported. In this way, internal and Extrinsic consistency work was carried out.

\section{Implementation Process}

The activities are prepared to be implemented for 10 weeks, taking into account the annual teaching plan. The activities were implemented once a week. Each student performed this activity individually. The teacher explained the subject each week and then gave the students the task of the WTL activity. At the beginning of every following week, he collected these activities and gave the necessary feedback. 
The implementation schedule was prepared by taking into account the annual plan created by the researcher and the course teacher. According to this calendar, the pre-test application was carried out on September 19, 2018 in the first week of the academic year. After the pre-test application, the experimental implementation was carried out in accordance with the implementation schedule. EG1 students were taught with the WTL activity, EG2 students were taught with WTL and Feedback (WTL+F), and students were taught with the Traditional Method (TM). Information of the experimental implementation is presented in Table 3.

Table 3.

Implementation Steps

\begin{tabular}{lllll}
\hline Week & Subject & EG1 & EG2 & CG \\
\hline 1 & MS & Pre-test & Pre-test & Pre-test \\
2 & Introduce yourself & WTL & WTL+F & TM \\
3 & Nationality & WTL & WTL+F & TM \\
4 & Family & WTL & WTL+F & TM \\
5 & Occupations & WTL & WTL+F & TM \\
6 & Birthday & WTL & WTL+F & TM \\
7 & What time is it? & WTL & WTL+F & TM \\
8 & Wh- Questions & WTL & WTL+F & TM \\
9 & Daily Routines & WTL & WTL+F & TM \\
10 & Simple Present Tense & WTL & WTL+F & TM \\
11 & Present Continuous Tense & WTL & WTL+F & TM \\
12 & MS & Post-test & Post-test & Post-test \\
13 & Interview & Interview & Interview & - \\
\hline
\end{tabular}

As shown in table 3, the implementation phase of the research was thirteen weeks; pre-test, posttest, and interview were carried out in three weeks $(23.07 \%)$ of this period, and WTL activity writing practice was carried out in ten weeks (76.93\%). The course teacher taught the subjects on a weekly basis. In the table, it is indicated which subject was taught mainly each week. The teacher taught the lesson in accordance with the MoNE curriculum; unlike the control group, he gave the WTL activity as homework in the experimental groups. The students who did the WTL activity as homework delivered their homework to their teachers in the first lesson of the following week. The CG students performed the activities and practices in the MoNE curriculum. After the students in EG1 submitted their assignments, the teacher checked the activities and evaluated them using general statements about how they could prepare better activities. After the students in EG2 submitted their assignments, the teacher evaluated the assignments and gave feedbacks in accordance with the motivation strategies specific for each student. In the first three weeks of the implementation period, the activity was carried out as an in-class activity in the last lesson of the week in order for the students to get used to the activity. During this period, the students asked the teacher their questions about the activity and completed the activities, and handed them over to the teacher at the end of that lesson hour. Twenty minutes of the forty-minute lesson was sufficient for this activity. At the end of three weeks, it was observed that the students got used to the activity completely and it was found appropriate by the researcher and the teacher to do it as an out-of-class activity. For the last seven weeks, WTL was implemented at the students' homes as an out-of-class activity. In the observation made by the teacher and the researcher, it was determined that the students made preparations for the activity while teaching a new topic after the fourth week. At the end of the lessons, where the teacher said that she had passed to a new topic and explained the new topic, some of the students asked the teacher questions about the activity they planned to do during the breaks. It was observed that some of the students designed, wrote, and drew the activities they planned to do during the breaks. 
These activities were obtained from two $9^{\text {th }}$ grade classes ( $\left.\mathrm{N}: 61\right)$. Students prepared these activities ( $\mathrm{N}: 610)$ for ten weeks. The activity was taken the following week from the students who could not deliver the activity on time due to their excuses (illness, family reasons, etc.). Since the activities of some students are more than one page, the total number of pages of the activities is 633 .

\section{Findings and Comment}

\section{Findings and Comments of the First Sub-Problem}

The findings and comments obtained from the tests according to the post-test scores corrected by the MS are presented below. The descriptive statistics of the post test of the motivation are presented in Table 4.

Table 4.

Descriptive Statistics for Post-test of MS

\begin{tabular}{llllll}
\hline Scale & Group & $\mathbf{N}$ & $\overline{\mathbf{X}}$ & sd & Adjusted Average \\
\hline \multirow{3}{*}{ Motivation } & EG1 & 31 & 4.81 & .48 & $4.78^{\mathrm{a}}$ \\
& EG2 & 30 & 5.40 & .27 & $5.39^{\mathrm{a}}$ \\
& CG & 30 & 4.43 & .61 & $4.43^{\mathrm{a}}$ \\
& Total & 91 & 4.88 & .62 &
\end{tabular}

In Table 4, it was determined that the order from the highest score to the least score according to the corrected post-test scores of the Motive dimension was EG2 ( $\mathrm{X}: 5.39)$, EG1 ( $\mathrm{X}: 4.78), \mathrm{CG}(\overline{\mathrm{X}}: 4.43)$. The ANCOVA test results applied to determine whether the difference in scores between the groups are significant are presented in Table 5.

Table 5.

ANCOVA Test Results of MS

\begin{tabular}{llllll}
\hline $\begin{array}{l}\text { Source of } \\
\text { Variance }\end{array}$ & $\begin{array}{l}\text { Sum of } \\
\text { Squares }\end{array}$ & sd & $\begin{array}{l}\text { Average of } \\
\text { Squares }\end{array}$ & $\mathbf{f}$ & $\mathbf{P}$ \\
\hline Pre-test & 1.24 & 1 & 1.24 & 6.74 & .01 \\
Group & 5.04 & 2 & 2.52 & 13.61 & .00 \\
Error & 15.74 & 85 & .18 & & \\
Total & 2202.27 & 91 & & & \\
\hline
\end{tabular}

According to the ANCOVA results presented in Table 5, it was observed that there was a significant difference between the post-test scores $\left(\mathrm{F}_{(2,85)}=13.61 ; \mathrm{p}<.05\right)$ adjusted according to the pretest scores of the groups. The Bonferroni test, which was performed to determine which groups favored the significant difference, is presented in Table 6.

Table 6.

Bonferroni Test Results of MS

\begin{tabular}{lllll}
\hline Sub-scale & Groups & Average Difference & Standard Error & P \\
\hline \multirow{2}{*}{ Motivation } & EG2-EG1 & $.61^{*}$ & .11 & .00 \\
& EG2-CG & $.96^{*}$ & .11 & .00 \\
& EG1-CG & $.35^{*}$ & .11 & .00 \\
\hline
\end{tabular}

Based on the results in Table 6, between EG2 and EG1 $(p<.05)$ in favor of EG2; between EG2 and CG $(p<.05)$ in favor of EG2; it was observed that there was a significant difference between EG1 and CG $(p<.05)$ in favor of EG1. According to these results, it can be interpreted that the experimental method applied creates a significant difference in motivation in favor of the experimental groups. The descriptive determinations of the value sub-scale and sub-factors of MS are presented in Table 7. 
Table 7.

Descriptive Statistics related to Value Sub-scale

\begin{tabular}{|c|c|c|c|c|c|c|}
\hline Sub-scale & Sub-factor & Group & $\mathbf{N}$ & $\overline{\mathbf{X}}$ & sd & Adjusted Average \\
\hline \multirow{16}{*}{ Value } & & EG1 & 31 & 5.22 & .57 & $5.20^{\mathrm{a}}$ \\
\hline & & EG2 & 30 & 5.29 & .43 & $5.27^{\mathrm{a}}$ \\
\hline & & CG & 30 & 4.454 & .78 & $4.32^{\mathrm{a}}$ \\
\hline & & Total & 91 & 4.99 & .71 & \\
\hline & \multirow{4}{*}{$\begin{array}{l}\text { Intrinsic } \\
\text { Target }\end{array}$} & EG1 & 31 & 5.26 & .83 & $5.27^{\mathrm{a}}$ \\
\hline & & $\mathrm{EG} 2$ & 30 & 5.23 & .70 & $5.31^{a}$ \\
\hline & & $\mathrm{CG}$ & 30 & 4.22 & .90 & $4.03^{a}$ \\
\hline & & Total & 91 & 4.91 & .94 & \\
\hline & \multirow{4}{*}{$\begin{array}{l}\text { Extrinsic } \\
\text { Target }\end{array}$} & EG1 & 31 & 5.26 & .834 & $5.16^{\mathrm{a}}$ \\
\hline & & $\mathrm{EG} 2$ & 30 & 5.23 & .70 & $5.41^{\mathrm{a}}$ \\
\hline & & CG & 30 & 4.22 & .90 & $4.15^{a}$ \\
\hline & & Total & 91 & 4.91 & .94 & \\
\hline & \multirow{4}{*}{ Task Value } & EG1 & 31 & 5.00 & .74 & $5.04^{a}$ \\
\hline & & EG2 & 30 & 5.15 & .68 & $5.09^{a}$ \\
\hline & & CG & 30 & 4.36 & 1.20 & $4.11^{\mathrm{a}}$ \\
\hline & & Total & 91 & 4.84 & .95 & \\
\hline
\end{tabular}

According to the corrected post-test scores of the Value sub-scale in Table 7, the order from the highest score to the least score is EG2 ( $\bar{X}: 5.27), E G 1$ ( $\bar{X}: 5.20)$, CG ( $\bar{X}: 4.32)$; in the intrinsic target sub factor, EG2 ( $\bar{X}: 5.27)$, EG1 ( $\mathrm{X}: 5.31), \mathrm{CG}(\overline{\mathrm{X}}: 4.03)$; in the Extrinsic target sub-factor EG2 ( $\overline{\mathrm{X}}: 5.42)$, EG1 $(\bar{X}: 5.16), C G(\bar{X}: 4.15)$; It was determined that the sub-factor of the task value was EG2 ( $\bar{X}: 5.09), E G 1$ $(\bar{X}: 5.04), C G(\bar{X}: 4.11)$. The ANCOVA test results, which were applied to determine whether the difference in scores between the groups was significant, are presented in Table 8.

Table 8.

ANCOVA Results of Value Sub-scale

\begin{tabular}{|c|c|c|c|c|c|c|c|}
\hline Sub-scale & Sub-factor & $\begin{array}{l}\text { Source of } \\
\text { Variance }\end{array}$ & $\begin{array}{l}\text { Sum of } \\
\text { Squares }\end{array}$ & sd & $\begin{array}{l}\text { Average of } \\
\text { Squares }\end{array}$ & $\mathbf{F}$ & $\mathbf{P}$ \\
\hline \multirow{16}{*}{ Value } & & Pre-test & 4.49 & 1 & 4.49 & 14.96 & .00 \\
\hline & & Group & 5.97 & 2 & 2.99 & 9.95 & .00 \\
\hline & & Error & 25.51 & 85 & .30 & & \\
\hline & & Total & 2314.09 & 91 & & & \\
\hline & \multirow{4}{*}{$\begin{array}{l}\text { Intrinsic } \\
\text { Target }\end{array}$} & Pre-test & 15.28 & 1 & 15.28 & 31.52 & .00 \\
\hline & & Group & 6.40 & 2 & 3.20 & 6.60 & .00 \\
\hline & & Error & 41.21 & 85 & .48 & & \\
\hline & & Total & 2275.75 & 91 & & & \\
\hline & \multirow{4}{*}{$\begin{array}{l}\text { Extrinsic } \\
\text { Target }\end{array}$} & Pre-test & 5.42 & 1 & 5.42 & 8.81 & .00 \\
\hline & & Group & 24.90 & 2 & 12.45 & 20.25 & .00 \\
\hline & & Error & 53.48 & 87 & .61 & & \\
\hline & & Total & 2275.75 & 91 & & & \\
\hline & \multirow{4}{*}{ Task Value } & Pre-test & 9.80 & 1 & 9.80 & 20.34 & .00 \\
\hline & & Group & 28.84 & 2 & 14.42 & 29.93 & .00 \\
\hline & & Error & 40.95 & 85 & .48 & & \\
\hline & & Total & 2215.19 & 91 & & & \\
\hline
\end{tabular}

Based on the ANCOVA results in Table 8 , in the Value sub-scale $\left(F_{(2,85)}=9.95 ; p<.05\right)$; In the intrinsic target sub-factor $\left(F_{(2.85)}=6.60 ; p<.05\right)$; in the extrinsic target sub-factor $\left.\left(F_{(2.85}\right)=20.25 ; p<.05\right)$; there is a significant difference between the scores of the groups in the task value sub-scale $\left(F_{(2,85)}=29.93 ; p<.05\right)$. The Bonferroni test, which was performed to determine which groups favored the significant differences, is presented in Table 9. 
Table 9.

Bonferroni Results of Value Sub-scale

\begin{tabular}{llllll}
\hline Sub-scale & Sub-factor & Groups & $\begin{array}{l}\text { Average } \\
\text { Difference }\end{array}$ & Standard Error & P \\
\hline \multirow{2}{*}{ Value } & & EG2-EG1 & .06 & .14 & .95 \\
& & $.94^{*}$ & .15 & .00 \\
& EG2-CG & $.87^{*}$ & .14 & .00 \\
\cline { 2 - 6 } & Intrinsic & EG2-EG1 & .03 & .18 & .96 \\
& Target & EG2-CG & $1.27^{*}$ & .18 & .00 \\
& EG1-CG & $1.23^{*}$ & .18 & .00 \\
\cline { 2 - 5 } & Extrinsic & EG2-EG1 & .26 & .22 & .74 \\
& Target & EG2-CG & $1.26^{*}$ & .22 & .00 \\
& & EG1-CG & $1.00^{*}$ & .20 & .00 \\
\cline { 2 - 5 } & \multirow{2}{*}{ Task Value } & EG2-EG1 & .05 & .18 & 1.00 \\
& EG2-CG & $.98^{*}$ & .18 & .00 \\
& & EG1-CG & $.92^{*}$ & .18 & .00 \\
\hline
\end{tabular}

According to the results presented in Table 9, in the value sub-scale, between EG2 and CG in favor of EG2 $(p<.05)$, between EG1 and CG in favor of EG1 $(p<.05)$; in the intrinsic target sub-factor, between EG2 and $C G$ in favor of EG2 ( $<<.05)$, between EG1 and CG in favor of EG1 ( $p<.05)$; In the Extrinsic target subfactor, between EG2 and CG, in favor of EG2 ( $<<.05)$, between EG1 and CG in favor of EG1 $(p<.05)$; in the task value sub-factor, between EG2 and CG, in favor of EG2 $(p<.05)$, between EG1 and CG there is a statistically significant difference in favor of EG1 $(p<.05)$. According to these results, it can be interpreted that the WTL activity applied to the experimental groups enabled the students to be more effective than the CG students in providing value, internal goal setting, Extrinsic goal setting, and task value motivations. The analyzes of the expectation sub-scale, which is another sub-scale of MS, are presented below. The descriptive analysis results of the expectation sub-scale are presented in Table 10.

Table 10.

Descriptive Statistics of Expectancy Sub-scale

\begin{tabular}{|c|c|c|c|c|c|c|}
\hline Sub-scale & Sub-factor & Group & $\mathbf{N}$ & $\overline{\mathbf{X}}$ & sd & Adjusted Average \\
\hline \multirow{12}{*}{ Expectancy } & & EG1 & 31 & 5.02 & .72 & $5.10 a$ \\
\hline & & EG2 & 30 & 5.30 & .28 & $5.28 a$ \\
\hline & & CG & 30 & 4.55 & .75 & $4.29 a$ \\
\hline & & Total & 91 & 4.96 & .69 & \\
\hline & \multirow{4}{*}{$\begin{array}{l}\text { Self-Efficacy } \\
\text { Perception }\end{array}$} & EG1 & 31 & 4.90 & .80 & $5.03 a$ \\
\hline & & EG2 & 30 & 5.39 & .42 & $5.36 a$ \\
\hline & & $C G$ & 30 & 4.55 & .80 & $4.26 a$ \\
\hline & & Total & 91 & 4.95 & .77 & \\
\hline & \multirow{4}{*}{$\begin{array}{l}\text { Need for } \\
\text { Learning } \\
\text { Control }\end{array}$} & EG1 & 31 & 5.46 & .93 & $5.47 a$ \\
\hline & & EG2 & 30 & 5.12 & .50 & $5.14 a$ \\
\hline & & CG & 30 & 4.53 & 1.05 & $4.35 a$ \\
\hline & & Total & 91 & 5.04 & .93 & \\
\hline
\end{tabular}

Based on the corrected post-test scores of the Expectation sub-scale in Table 10, the order from the

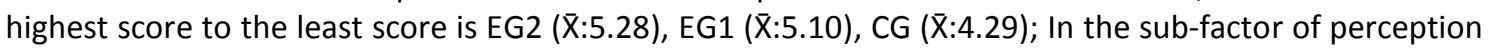
of self-efficacy, EG2 ( $\mathrm{X}: 5.36), \mathrm{EG1}(\overline{\mathrm{X}}: 5.03), \mathrm{CG}(\overline{\mathrm{X}}: 4.26)$; it was determined that the learning control need sub-factor is EG1 ( $\bar{X}: 5.47), E G 2(\bar{X}: 5.14), C G(\bar{X}: 4.35)$. The ANCOVA test results, which were applied to determine whether the difference in scores between the groups were significant, are presented in Table 11. 
iNCIRCi \& VARDAR- Çukurova Üniversitesi Eğitim Fakültesi Dergisi, 50(2), 2021, 877-906

Table 11.

ANCOVA Results of Expectancy Sub-scale

\begin{tabular}{|c|c|c|c|c|c|c|c|}
\hline Sub-scale & Sub-factor & $\begin{array}{l}\text { Source of } \\
\text { Variance }\end{array}$ & $\begin{array}{l}\text { Sum of } \\
\text { Squares }\end{array}$ & sd & $\begin{array}{l}\text { Average of } \\
\text { Squares }\end{array}$ & $\mathbf{F}$ & $\mathbf{P}$ \\
\hline \multirow{12}{*}{ Expectancy } & & Pre-test & 6.90 & 1 & 6.90 & 26.33 & .00 \\
\hline & & Group & 10.33 & 2 & 5.16 & 19.69 & .00 \\
\hline & & Error & 22.30 & 85 & .26 & & \\
\hline & & Total & 2286.40 & 91 & & & \\
\hline & \multirow{4}{*}{$\begin{array}{l}\text { Self-Efficacy } \\
\text { Perception }\end{array}$} & Pre-test & 7.72 & 1 & 7.72 & 23.87 & .00 \\
\hline & & Group & 15.78 & 2 & 7.89 & 24.38 & .00 \\
\hline & & Error & 27.50 & 85 & .32 & & \\
\hline & & Total & 2285.73 & 91 & & & \\
\hline & \multirow{4}{*}{$\begin{array}{l}\text { Need for } \\
\text { Learning } \\
\text { Control }\end{array}$} & Pre-test & 12.36 & 1 & 12.36 & 21.07 & .00 \\
\hline & & Group & 7.85 & 2 & 3.92 & 6.69 & .00 \\
\hline & & Error & 49.87 & 85 & .58 & & \\
\hline & & Total & 2397.06 & 91 & & & \\
\hline
\end{tabular}

As reported in Table 11, in the Expectation sub-scale $\left(F_{(2.85)}=19.69 ; p<.05\right)$; in the self-efficacy perception sub-factor $\left(F_{(2.85)}=24.38 ; p<.05\right)$; There is a significant difference between the scores of the groups in the need for learning control sub-scale $\left(F_{2.85}=6.69 ; p<.05\right)$. The Bonferroni test, which was performed to determine which groups favored the significant differences, is presented in Table 12.

Table 12.

Bonferroni Results of Expectancy Sub-scale

\begin{tabular}{llllll}
\hline Sub-scale & Sub-factor & Groups & $\begin{array}{l}\text { Average } \\
\text { Difference }\end{array}$ & $\begin{array}{l}\text { Standard } \\
\text { Error }\end{array}$ & P \\
\hline \multirow{3}{*}{ Expectancy } & & EG2-EG1 & .18 & .13 & .55 \\
& & EG2-CG & $.98^{*}$ & .14 & .00 \\
& EG1-CG & $.80^{*}$ & .14 & .00 \\
\cline { 2 - 6 } & Self-Efficacy & EG2-EG1 & .33 & .15 & .09 \\
& Perception & EG2-CG & $1.09^{*}$ & .16 & .00 \\
& EG1-CG & $.76^{*}$ & .16 & .00 \\
\cline { 2 - 6 } & Need for & EG2-EG1 & -.33 & .19 & .30 \\
& Learning & EG2-CG & $.78^{*}$ & .21 & .00 \\
& Control & EG1-CG & $1.11^{*}$ & .20 & .00
\end{tabular}

As stated in Table 12, in the expectation sub-scale, between EG2 and CG in favor of EG2 ( $p<.05)$, between EG1 and CG in favor of EG1 ( $<<.05)$; In the sub-factor of perception of self-efficacy, between $E G 2$ and CG in favor of EG2 $(p<.05)$, between EG1 and CG in favor of EG1 $(p<.05)$; A statistically significant difference was found between EG2 and CG in favor of EG2 $(p<.05)$ and between EG1 and CG in favor of EG1 $(p<.05)$ in the need for learning control sub-factor. According to these results, it can be interpreted that the WTL activity applied to the experimental groups enabled the students to be more effective in their expectations, self-efficacy perception, and learning control needs motivations than the CG students. The analyzes of the test anxiety sub-factor belonging to the Affective sub-scale, which is the other sub-scale of MS, are presented below. The descriptive analysis results of the affective subscale are presented in Table 13.

Table 13.

Descriptive Statistics of Affection Sub-scale

\begin{tabular}{lllllll}
\hline Sub-scale & Sub-factor & Group & N & $\overline{\mathbf{X}}$ & sd & Adjusted Average \\
\hline \multirow{3}{*}{ Affection } & Test & EG1 & 31 & 4.84 & .92 & $4.88 \mathrm{a}$ \\
& Anxiety & EG2 & 30 & 4.32 & 1.08 & $4.37 \mathrm{a}$ \\
& CG & 30 & 4.07 & .77 & $4.00 \mathrm{a}$ \\
& & Total & 91 & 4.4 & .98 & \\
\hline
\end{tabular}


According to the adjusted final test scores for the sub-factor of exam anxiety in Table 13, the ranking from maximum to minimum score was found to be EG1 (X:4.88), EG2 (X:4.37), CG (x:4.00). The results of the ANCOVA test, which were applied to determine whether the score differences between the groups were significant, are presented in Table 14.

Table 14.

ANCOVA Results of Affection Sub-scale

\begin{tabular}{llllll}
\hline $\begin{array}{l}\text { Source of } \\
\text { Variance }\end{array}$ & Sum of Squares & Sd & $\begin{array}{l}\text { Average of } \\
\text { Squares }\end{array}$ & F & P \\
\hline Pre-test & 2.24 & 1 & 2.24 & 2.59 & .11 \\
Group & 11.21 & 2 & 5.61 & 6.47 & .00 \\
Error & 75.32 & 87 & .86 & & \\
Total & 1864.68 & 91 & & & \\
\hline
\end{tabular}

As reported in Table 14, there is a significant difference $\left(F_{(2,87)}=6.47 ; p<.05\right)$ between the groups' post-test scores adjusted for their pre-test scores. The Bonferroni test, which was performed to determine which groups favored the significant difference, is presented in Table 15.

Table 15.

Bonferroni Results of Affection Sub-scale

\begin{tabular}{llllll}
\hline Sub-scale & Sub-factor & Groups & $\begin{array}{l}\text { Average } \\
\text { Difference }\end{array}$ & $\begin{array}{l}\text { Standard } \\
\text { Error }\end{array}$ & $\mathbf{P}$ \\
\hline \multirow{2}{*}{ Affection } & \multirow{2}{*}{ Test Anxiety } & EG2-EG1 & -.51 & .23 & .10 \\
& & EG2-CG & .37 & .25 & .43 \\
& & EG1-CG & $.88^{*}$ & .24 & .00 \\
\hline
\end{tabular}

As stated in Table 15, there is a significant difference between EG1 and CG $(p<.05)$ in favor of EG1. Based on these results, it can be interpreted that the experimental method applied is ineffective in making a significant difference in test anxiety. It can be interpreted that the activity of WTL creates a statistically significant difference between the experimental groups and CG in motivation strategies, and this difference is effective in favoring both experimental groups, except for the test anxiety sub-factor.

\section{Findings and comments of the Second Sub-Problem}

In this section, the sub-themes of the motivation main theme, "value, expectation and affective", and the definitions made about the sub-themes within these three sub-themes are included. The students were first asked how the activities affected their interest in the lesson. Five of the students ( $\mathrm{N}: 5 ; \mathrm{S} 1, \mathrm{~S} 2, \mathrm{S3}, \mathrm{S} 5, \mathrm{~S} 6: 83.33 \%$ ) stated that they increased their interest. In addition, the students stated that the lesson became easier, they could express themselves, and their situation of getting help from the teacher increased. The definitions regarding the main theme of motivation are shown in Table 16 below.

Table 16.

Descriptive Statistics of Statements

\begin{tabular}{llll}
\hline Sub-Themes & Codes & $\mathbf{N}$ & $\mathbf{f ~ ( \% ) ~}$ \\
\hline \multirow{4}{*}{ Value } & Interesting (increasing interest, curiosity) & 5 & 83 \\
\cline { 2 - 4 } & Importance (Value, able to use) & 6 & 100 \\
\cline { 2 - 4 } & State of being better & 5 & 83 \\
\cline { 2 - 4 } & Become meaningful & 4 & 67 \\
\cline { 2 - 4 } & The state of being useful & 6 & 100 \\
\hline \multirow{5}{*}{ Expectancy } & The state of increasing faith & 5 & 83 \\
\cline { 2 - 4 } & State of being better (success) & 6 & 83 \\
\cline { 2 - 4 } & Facilitation & 5 & 83 \\
\cline { 2 - 4 } & Self-confidence, Self-efficacy & 4 & 67 \\
\cline { 2 - 4 } & Self-Value (positive statements) & \multicolumn{2}{c}{} \\
\hline
\end{tabular}


inCiRCi \& VARDAR- Çukurova Üniversitesi Eğitim Fakültesi Dergisi, 50(2), 2021, 877-906

\begin{tabular}{llll}
\hline \multirow{4}{*}{ Affection } & Liking & 6 & 100 \\
\cline { 2 - 4 } & being enough & 5 & 83 \\
\cline { 2 - 4 } & Anxiety (worry, excitement) & 1 & 17 \\
\cline { 2 - 4 } & Despondency & 0 & 0 \\
\hline
\end{tabular}

Table 16, which shows the compatibility of the expressions used by the students related to the main theme of Motivation, with the sub-themes, shows how frequent the expressions are used. In the findings, it was determined that the most frequent ( $N: 6 ; f: 100 \%)$ expressions were valuable, useful, facilitating, and loving. On the other hand, the expressions of low mood ( $N: 1 ; f: 17 \%)$ and anxiety (worry, excitement) ( $\mathrm{N}: 0 ; \mathrm{f:0 \%}$ ) were found to be the least frequently used expressions. Direct quotations from student opinions concerning the identified themes are given below:

... actually, I was a little strange at first. So I couldn't understand exactly how it would happen, but while doing it, I started to understand. When I talked to my friends at other schools, I asked them, for example, they don't do such things. It was different, the first week was a bit confusing. Actually, the activity was easy, but how I felt was confusing. Then, as I started doing it, I found it useful. For example, in the lesson after the activity, I had difficulty remembering the previous lesson, but when the shapes and graphs came to my mind, I started to remember them more easily. The lesson became easier and more interesting... (S1)...

The expressions "different, useful, facilitating, remembering, meeting with peers, interesting" used by the student coded S1 show that the student values the lesson and his motivation increases. The fact that the activity is confusing at first and then finds it meaningful and likes it as he sees its benefits, adapting to the new situation, combining this situation with positive emotions also shows that $s /$ he uses a critical thinking strategy. The fact that $s /$ he remembers by analogy with figures shows that $s /$ he learned the information by coding and therefore used the exposition strategy. It can be commented that the student sees the benefit as he/she does the WTL activity and that this activity increases his/her interest in the lesson. A direct quote from the student coded S6 is as follows:

... dear teacher, my English is not very good. It wasn't very good in middle school either. Now I'm not like I was in middle school. I've grown since I got to high school, I'll be better. I said English would be the same again. You said, "You can also do this activity in Turkish". Then I said to myself "of course I could then". I drew even more different things, such as a modified car, TOFAŞ. Other than that... When I don't understand, it is easier when I ask the teacher in Turkish. I couldn't ask in English, but now that I understood it, I started asking questions, the teacher said, so he liked it...(S6)

The expression "I will be better" used by the student coded S6 shows the belief of the student about his/her performance. It can be stated that the student's self-efficacy perception develops. Because the student states that he was not successful in this course in his previous school life. In addition, it can be commented that the free use of Turkish in the activity contributed positively to this situation of the student. The statement of the student "...now I understand..." shows that awareness has occurred in his learning and the statement "...I started to ask questions..." shows that the student is motivated towards the lesson and also succeeds in maintaining this motivation. It can be stated that positive changes occur in the student's course performance, interest and belief. It can be commented that this situation contributes positively to the motivation of the student.

Secondly, the students were asked how WTL activities affected their feelings towards the exam. All of the students (6: S1, S2, S3, S4, S5, S6: 100\%) stated that the activities had a positive effect on their grades. It can be stated that the WTL activity reduces students' test anxiety. Four of the students (4: S1, S2, S3; S5: 66.66\%) stated that their fear of exams disappeared completely, while two (2: S4, T6 33.33\%) stated that fear was replaced by a feeling of excitement. This situation reveals the feelings developed by the students regarding the affective dimension. In addition, it can be stated that the fact that students 
who express positive opinions determine the content by making use of their own lives and experiences in the activities contributes to this situation. The identified themes and related student opinions are given below:

...the contents we do in the lesson and in the activity come in the exam. Since we do the activities according to ourselves, it stays in our mind, so the exam is easy. I can't say I'm afraid... (S1))

The student coded S1 has learned the subjects he has done in the lesson; it can be commented that he is interested in the lesson, that he remembers the content he learned in this lesson, and that his exam anxiety disappears because of this remembering.

$$
\text { ...it definitely reflected positively on my grades... (S2) }
$$

The student coded S2 gave a clear answer in his statement on this subject and used the word "certain". It can be stated that this situation reduces anxiety and improves expectations.

...I think the effect is very good because it has increased... (S5)

... I used to not understand much, and I would get bored in the exam. Now, because we wrote it before and when I think about what I asked the teacher before, I get better grades. My grade was bad before... (S6)

The expressions "reflected positively, positively, improved, getting better grades" of the students show that the beliefs and interest of the students in performance increased, this increase contributed to their motivation and they developed positive emotions. It can also be understood from the expression that test anxiety has decreased and that he is not bored in the exam. It can be commented that WTL activities reduce students' test anxiety.

Five of the students (5: S1, S2, S3, S4, S5: 83.33\%) stated that the activities had a positive effect on their belief that they would get high grades in this course. It can be stated that the students' views on the "expectation" theme are positive. The identified themes and related student opinions are given below:

...I saw what I didn't understand in the class, so I thought that I would get a high grade...(S1)

It can be commented that the student coded S1 identified his deficiencies and made up for them while doing the activities, thus performing an efficient study, and contributing to the motivation of this situation, which he had positive expectations thanks to this study.

"...it increased when I got five in the first exam, of course, my teacher..." (S3)

The success of the student coded S3 in the exam has contributed to raising his expectation towards the course and increasing his interest in the course.

"...if I enter now, I will get at least 90..."(S4)

It can be stated that the expectation and self-efficacy belief of the student coded S4 are high.

"... my belief was always high, but I can say that it has become more secure..." (S5)

It can be stated that the expectation of the student coded S5 was high before the activity, but his self-efficacy belief increased with this activity. This situation makes his expectation more faithful. It can be commented that this situation contributes to his motivation.

Five of the students (5: S1, S2, S3, S5, S6: 83.33\%) stated that there was no need for preparation for the exam other than these activities. The adequacy of the activity was used to gain insight into the development of students' performance beliefs. Direct quotations from the opinions of students coded S2 and S5 are presented below: 
iNCIRCi \& VARDAR- Çukurova Üniversitesi Eğitim Fakültesi Dergisi, 50(2), 2021, 877-906

... I think it's enough, our teacher said so. There are other assignments as well. It supports them. Also, I do it before the lesson so that I can remember the homework. In short, I think it's enough... (S2)

It can be stated that the student coded S2 performs this activity together with other assignments, and by doing it before the lesson, he/she has the aim of repeating, thus gaining control over his/her own learning process, making arrangements for his/her goals and seeing the activity as sufficient.

... that's enough, teacher, when we see the questions, we think of what we are doing, it is easier. Anyone can do so, they can look at other sources, but I did not look. Also, since these are my own writings, it is easier to understand briefly...(S5)

It can be understood from the expression of students coded S5, "Because these are my own writings, it is easier to understand in a short time". It can be commented that this situation, which transforms these activities into an effective tool on the way to the course and his own goals, enables him to use the metacognitive strategies of goal setting and analysis effectively.

In the light of the themes and sub-themes provided from the data obtained from the opinions of the students, their views on the themes of "internal-Extrinsic goal setting, task value, self-efficacy perceptions, learning control beliefs, test anxiety" and "value, expectation and affection" sub-themes changed positively, It can be commented that this situation has a positive contribution to their motivation.

\section{Conclusion and Discussion}

The use of WTL activities in the English lesson positively affects the motivation of the students towards the lesson. Some studies on WTL and motivation in the literature (Iran-Nejad, Watts, Venugopalan, Xu, 2006; Iran-Nejad and Stewart, 2011; Morozov, 2011; Allan and Driscoll, 2014; Lang, 2018a; 2018b; Tate and Warschauer, 2018; Qian, 2019; Wright, HoEGes, Zimmer, \& McTigue, 2019) have similar as this study's result. However, according to research on learning and motivation, it is not possible to talk about a single factor affecting motivation towards learning. Harrington and Zakrajsek (2017) stated that making sense of the taught concepts and identifying them with the concepts increases the motivation necessary for students to learn the content. They stated that students' understanding new concepts together with the real world helps them to keep them in their minds longer and this is one of the most important factors to increase motivation. They suggested that this was because motivated students were ready to pay more attention to the lesson and put more effort into learning. These statements support the results of this research.

Another result that emerged within the scope of the research is related to test anxiety. According to the pre-tests, the result in favor of EG2 was in favor of CG between EG1 and CG according to the posttests. This can be interpreted as the experimental method applied to EG2 was successful in reducing test anxiety, but the experimental method applied to EG1 was unsuccessful. It can be stated that this difference is due to the effect of "feedback" on reducing test anxiety, but this difference is not statistically significant.

Although the word anxiety is used in a negative sense, it does not always cause a negative result. In fact, not having any anxiety is not a preferred situation in terms of language learning. Excessive anxiety causes students to fail. There are students who turn back from the door of the classroom without taking the exam due to excessive anxiety, and these students are considered unsuccessful in the foreign language course because they do not take the exam. Such students should be taught techniques to cope with the feeling of test anxiety (Beklenen, 2015). The results of the studies on how test anxiety affects language teaching in the classroom can be expressed in three categories (Ellis, 2008):

- Anxiety is beneficial for language learning.

- Anxiety has a negative impact on language learning.

- Anxiety is the result, not the cause, of language learning difficulties. 
Considering these three results obtained from academic studies; it is seen that the first determination about anxiety is positive, the second one is negative, and the third one is the result, not the cause. Exam anxiety, which is an academic assessment, is one of the components of foreign language anxiety. However, there is no consensus among researchers that anxiety is a cause or an effect. In this study, the result is that the students who are more successful in terms of motivation strategies have high test anxiety. This situation is a common situation in perfectionist classrooms. What is meant by the expression perfectionist is the teaching-learning environment in which students or teachers are always concerned about keeping the level of success at the top (Walsh \& UgumbaAgwunobi, 2002). Students in such classes can also influence other students. Another value factor affecting this situation is the attitude of the teacher. However, test anxiety; can be affected by the physical conditions of the exam environment, course load, the anxiety of previous exams, gender, exam invigilator, exam duration, whether there are other exams on the same exam day. Therefore, test anxiety is a difficult motivation strategy and it is a type of anxiety that is difficult to reduce for students learning English in Turkey unless the variables are defined and controlled according to their effect values. Among the recommended methods for coping with test anxiety are learning positive thinking techniques, listing anxiety-causing situations/causes and discussing measures, rewarding this behavior when anxiety is coped with, analyzing emotions after the exam, etc. (Oxford, 2002). WTL activities can be used as a tool to implement these measures. First of all, it can be used to reveal the causes of test anxiety, then to design different activities according to the identified causes, or to give feedback to students on this subject by using the WTL activity.

Based on the fact that motivation is an important factor in the success of the students (Gottfried, 1985; Pintrich and de Groot, 1990; Zimmerman and Pons, 1990; Acat and Kosgeroglu, 2006; Livingston, 2017; Dornyei, 2019; Hart, 2019; Özhan ve Kocadere, 2020; Stupnisky, Hall and Pekrun, 2019), it can be stated that WTL activities are important activities for the accomplishment of the student. It was concluded that WTL activities are an effective tool for ensuring the motivation of students in English class when used in harmony with other factors affecting motivation.

\section{Suggestions}

\section{Suggestions for Teachers}

Teachers,

- should detect the mistakes of the students before the exams by using the WTL activities.

- should forward the feedbacks about the detected errors to the students via WTL.

- can observe whether students have corrected their mistakes by using WTL activities.

- can motivate their students towards the lesson with the activities of WTL.

\section{Suggestions for Researchers}

Researchers,

- $\quad$ can conduct research with students with a higher level of foreign language, in which the entire activity is done in the target foreign language.

- can conduct research on the effects of WTL activities at different educational levels.

In this study, all the rules specified to be followed within the scope of the "Higher Education Institutions Scientific Research and Publication Ethics Directive" were complied with. None of the actions specified under the title of "Actions Contrary to Scientific Research and Publication Ethics", which is under the second part of the directive, have been taken. 


\section{Türkçe Sürümü}

Giriş

Dünya genelinde öğretim programları belirli aralıklarla çağın, alanın ve sektörün ihtiyaçlarına uygun olarak güncellenmektedir. Programdaki değişimlerle birlikte öğrenme yaklaşımları, yöntem ve tekniklerde farklılaşmalar ortaya çıkmaktadır (Çalışkan ve Çangal, 2013). Türkiye'de öğretim programı değişikliklerini Millî Eğitim Bakanlığı, çağın gerekliliklerine uygun olarak yapmaktadır. Bu değişikliklerden en güncel olanı, 2017-2018 eğitim öğretim yılında birçok programla birlikte İngilizce dersi öğretim programında yapılan değişikliktir. Yenilenen yabancı dil öğretim programlarıyla birlikte Türkiye'de İngilizce öğretimi 2. sınıfta başlayarak 12. sınıfa kadar devam etmektedir.

Yenilenen programların temel adlığı yaklaşım, iletişimsel yaklaşım olarak belirlenmiştir (MEB, 2018a). Programlar seviyelendirilirken Avrupa Birliği Ortak Dil Çerçeve Programı (ABODÇP) (CoE, 2011) dikkate alınmış ve ilköğretim İngilizce öğretim programının öğrenme hedefi A2 seviyesi olarak belirlenmiştir. A1 seviyesinden başlayan ve $A 2$ seviyesine kadar devam eden bir planlama yapıldığı görülmektedir. Her ne kadar bu seviyede ABODÇP'de dört becerinin de aynı seviyede ilerlemesi gerektiği ifade edilmiş olsa da Türkiye'de İngilizce öğretim programlarında dört beceri aynı düzeyde ilerlememektedir (MEB, 2018a; Seçkin, 2011; Paker, 2012). Programlarda dinleme ve konuşma becerilerine ağırlık verilirken okuma ve yazma becerilerinin sınırlı olarak hedeflenmiştir (MEB, 2018a). Bu bir olumsuzluk gibi görülse de olumlu bir durumdur ve sebebi temele alınan iletişimsel yaklaşımdır. Bu yaklaşımla öğrencilerin iletişim becerileri, özellikle konuşma becerileri ön planda tutulmaktadır (Aliş, 2008; Güneş, 2011). Öğrencilerin yaş ve gelişim seviyeleri göz önünde bulundurulduğunda bu durumun doğal dil öğrenme sürecine uygun olduğu ifade edilebilir. Çünkü bireyler dünyaya geldiklerinde ilk olarak dinleme ve konuşma becerisini edinirler. Daha sonra okuma ve en son olarak da yazma becerisini öğrenirler (Terrell, 1977; Krashen ve Terrell, 1983; Cameron, 2001; Young, Hazarika, Poria ve Cambria, 2018).

Eğitim programı gibi öğrenmeyi dışsal olarak etkileyen faktörlerin yanında öğrenmeyi etkileyen "güdü"lenme gibi önemli duyuşsal faktörler de bulunmaktadır. Güdülenme, öğrenenin öğrenmeye dair inancı olarak tanımlanabilir. Yabancı dil eğitiminde bu tanım öğrenenin yabancı dil öğrenebileceğine dair inancıdır. Yabancı dil öğreniminde ve ediniminde güdülenme anahtar bir kavramdır. Güdülenme alanında yapılan modellemeler güdünün teorik temeli hakkında fikir sahibi olmaya yardımcı olsa da öğretmenler ve araştırmacılar; güdülenmeyi artıran, sınıf içerisinde kullanılabilen uygulanabilir yöntem, teknik ve etkinlilere intiyaç duyulmaktadır (Lasagabaster, Doiz ve Sierra, 2014). Teorik olarak kurgulanan ve kuramdan uygulamaya doğru bir yöne sahip olan araştırmalar gerçek sınıf ortamında hedeflenen güdüyle elde edilen güdü arasındaki boşluğu doldurmak için yetersiz kalmaktadır. Bu yüzden güdülenmeyle ilgili araştırmaların uygulamadan kurama doğru bir yöne evirilmesi daha işevuruk bir yaklaşımdır. Bu amaç doğrultusunda güdülenmeyi artırmak için öğrenme öğretme ortamında daha fazla deneysel çalışmaya ihtiyaç duyulmaktadır. Bu araştırmanın amacı İngilizce dersinde uygulanan ÖAY etkinliklerinin Güdülenme Stratejilerine etkisini araştırmaktır. Bu amaç doğrultusunda aşağıdaki sorulara cevap aranmaktadır:

1) Deney ve kontrol gruplarında yer alan öğrencilerinin Güdülenme Stratejilerinden (GS) aldıkları ön test puanları kontrol altına alındığında, son test puanları arasında istatistikî olarak anlamlı bir fark var mıdır?

2) Deney Grubu öğrencilerinin ÖAY etkinliklerinin Güdülenme Stratejilerine etkisi hakkındaki görüşleri nasıldır? 


\section{Yöntem}

\section{Çalışma Grubu}

Araştırmanın çalışma gurubunu 2018-2019 eğitim-öğretim yılında Karadeniz Bölgesinin batısındaki bir ilçede bulunan 91 tane 9. sınıf öğrencisi oluşturmaktadır. Çalışma gurubunda üç ayrı öğrenci grubu (KG, DG1, DG2) bulunmaktadır. Çalışma grubuna ilişkin bilgiler Tablo 1'de sunulmuştur.

Tablo 1.

Çalışma Grubuna Ait Bilgiler

\begin{tabular}{lllll}
\hline Gruplar & Cinsiyet & N & Yaş & $\begin{array}{l}\text { 8. Sınıf Ingilizce Not } \\
\text { Ortalaması }\end{array}$ \\
\hline \multirow{2}{*}{ KG } & Kız & 16 & 13.50 & 71.25 \\
& Erkek & 14 & 13.29 & 70.36 \\
DG1 & Kız & 17 & 13.41 & 62.94 \\
& Erkek & 14 & 13.14 & 66.07 \\
DG2 & Kız & 17 & 13.23 & 67.06 \\
& Erkek & 13 & 13.61 & 63.46 \\
Toplam & Kız & 50 & 13.38 & 67.08 \\
& Erkek & 41 & 13.35 & 66.63 \\
\hline
\end{tabular}

Tablo 1 incelendiğinde araştırmaya katılan toplam öğrenci sayısının 91 (Kız, N:50; Erkek, N:41), Kontrol Grubunun (KG) 30 (Kız, N:16; Erkek, N:14), Birinci Deney Grubunun (DG1) 31 (Kız, N:17; Erkek, $\mathrm{N}: 14$ ), İkinci Deney Grubunun (DG2) ise 30 (Kız, N:17; Erkek, N:13) olduğu görülmektedir. Öğrenci yaş ortalamaları KG'de kızların 13.50, erkeklerin 13.29; DG1'de kızların 13.41, erkeklerin 13.14; DG2'de kızların 13.23, erkeklerin 13.61 ve toplamda kızların 13.38 , erkeklerin $13.35^{\prime}$ dir. Öğrencilerin İngilizce dersinden bir önceki eğitim öğretim yılında aldıkları not ortalaması KG'de kızların 71.25, erkeklerin 70.36; DG1'de kızların 62.94, erkeklerin 66.07; DG2'de kızların 67.06, erkelerin 63.46 ve toplamda kızların 67.08, erkeklerin 66.63'tür. Öğrencilerin yaşa ve nota göre dağılımının birbirine denk olduğu ifade edilebilir.

\section{Veri Toplama Araçları}

\section{Güdülenme Stratejileri Ölçeği}

Güdülenme Stratejileri Ölçeği GSÖ, Amerika Birleşik Devletleri'nde bulunan Michigan Üniversitesi koordinatörlüğündeki Yüksek Öğretimi ve Öğrenmeyi Geliştirme Ulusal Araştırma Merkezi (National Center for Research to Improve Postsecondary Teaching and Learning) tarafından 1982 yılından 1986 yılına kadar süren bir çalışma sonucunda oluşturulmuştur. Ölçeğin orijinal ismi Motivated Strategies for Learning Questionnaire (MLSQ)'dir. Büyüköztürk, Akgün, Kahveci ve Demirel (2004) tarafından Türkçeye Güdülenme ve Öğrenme Stratejileri Ölçeği (GÖsÖ) olarak çevrilmiştir. Ölçeğin Türkçe formu iki farklı üniversitede 852 (Kadın, N:600, \%70,4; Erkek, N:208, \%24,4) öğrenciyle uygulanmıştır. GÖsÖ’nün iki ana boyutu olan Güdülenme Stratejileri Ölçeği (GSÖ) ve Öğrenme Stratejileri Ölçeği (ÖsÖ)'nin yapı geçerliklerini incelemek için açımlayıcı ve doğrulayıcı faktör analizi yapılmıştır. Ölçeğin 81 madde, GSÖ’nün altı faktörlü, ÖsÖ’nün ise dokuz faktörlü bir yapıdan oluştuğu tespit edilmiştir.

Ölçek 7'li likert tipi bir formdadır. Katılımcılar maddelere ilişkin katılma düzeylerini; (1) benim için kesinlikle yanlış ile (7) benim için kesinlikle doğru arasında bir değer belirterek işaretlemektedirler. Ölçeğin herhangi bir bölüm, alt boyut ya da alt ölçeğinden alınan yüksek puan ilgili birimle alakalı özelliğin yüksek olduğunu, düşük puan ise özelliğin düşük olduğunu ifade etmektedir. Bu araştırmada ölçeğin Güdülenme Stratejileri Bölümü GSÖ ayrı bir ölçek olarak kullanılmıştır. Güdülenme bölümüyle ilgili bilgiler Tablo 2'de verilmiştir. 
Tablo 2.

Güdülenme Alt Boyutu Madde Dağılımı

\begin{tabular}{clll}
\hline Alt Boyut & Alt faktör & Md Sayısı & Maddeler \\
\hline \multirow{2}{*}{ Değer } & İçsel Hedef Düzenleme & 4 & $1,16,22,24$ \\
& Dışsal Hedef Düzenleme & 4 & $7,11,13,30$ \\
& Görev Değeri & 6 & $4,10,17,23,26,27$ \\
\hline \multirow{2}{*}{ Beklenti } & Öz Yeterlik Algısı & 8 & $5,6,12,15,20,21,29,31$ \\
& Öğrenme Kontrolü Innancı & 4 & $2,9,18,25$ \\
\hline Duyuşsal & Sınav Kaygısı & 5 & $3,8,14,19,28$ \\
\hline
\end{tabular}

Tablo 2'de yer alan Güdülenme bölümü üç alt boyut ve altı alt faktörden meydana gelmektedir. Ölçeğin alt boyutları; Değer, Beklenti ve Duyuşsaldır. Değer alt boyutu üç alt faktörden meydana gelmektedir; İçsel Hedef Düzenleme, Dışsal Hedef Düzenleme, Görev Değeri. Beklenti alt boyutunda iki alt faktör bulunmaktadır; Öz Yeterlilik Algısı ve Öğrenme Kontrolü İhtiyacı. Duyuşsal alt boyutu ise Sınav Kaygısı alt faktöründen meydana gelmektedir. Güdülenme bölümü toplamda 31 maddeden oluşmaktadır. Bu maddelerden 3, 8, 14, 19, 28. maddeler ters kodlanan maddelerdir.

\section{Görüşme soruları}

Görüşme soruları araştırmacı tarafından ilgili literatür taranarak meydana getirilmiştir. Talim ve Terbiye Kurulu Başkanlığı'nda çalışan altı alan öğretmeni ve iki program uzmanından görüş alınmıştır. Sorular araştırmanın bağımlı değişkeni olan güdülenme stratejileri başlığı altında üç ana soru olarak hazırlanmıştır. Görüşme soruları üç adet ortaöğretim öğrencisiyle pilot çalışma olarak uygulandıktan sonra tüm soruların verimli bir biçimde çalıştığı tespit edilmiştir. Deneysel yöntemin uygulamasından bir hafta sonra yani 2018-2019 eğitim öğretim yılı 13. haftası görüşme soruları 6 öğrenciye (DG1, N:3; DG2, $\mathrm{N}: 3)$ sorularak veriler toplanmıştır.

\section{Veri Analizi}

Öncelikle GSÖ’den elde edilen nicel veriler analiz edilmiştir. Nicel kısımda; gruplar, testlerden aldıkları puanlara göre yüksek başarıdan düşük başarıya doğru sıralanmıştır. Daha sonra grupların testlerden almış oldukları puanların farklılaşıp farklılaşmadığını tespit etmek için varyans analizi testi (ANOVA) uygulanmıştır. Varyans analizi sonucunda aralarında fark olan grupların hangi grup puan lehine farklılaştığını tespit etmek için post hoc testleri uygulanmıştır. Bu analizin ardından homojen dağılım sergileyen verilere Bonferroni, homojen dağılmayan verilere ise Tamhane post hoc testi uygulanarak hangi gruplar arasında fark meydana geldiği tespit edilmiştir. Post hoc testlerinde en çok tercih edilen paratmetrik testler LSD ve Bonferronidir (Kayri, 2009). LSD yöntemi, standart testlerini mümkün olan tüm grup ortalaması çiftlerine uygular. LSD testi, farklılığın belirleneceği grup sayısının 3'ten fazla olması durumunda tercihi sakıncalı görülen bir post hoc istatistiğidir (Saville, 1990) çünkü grup sayısı arttıkça grup başına hata miktarı da artmaktadır. Bundan dolayı, karşılaştırması yapılan grup sayısının çok olması durumunda LSD çoklu karşılaştırma istatistiğinin kullanılmaması gerekmektedir (Williams ve Abdi, 2010). LSD testi, matematiksel olarak da I. tip hataya karşı oldukça korunmasız bir özellik taşımaktadır (Efe, vd., 2000). Bu yüzden Bonferroni testi tercih edilmiştir. Bonferroni testi (Dunn yordamı olarak da anılır) ve yanlış pozitif oranının belirtilen değeri geçmediğinden emin olmak için sıkı bir önem düzeyinde gerçekleştirilir. Yaygın kullanılan çoklu bir karşılaştırma testi olup, "eşit örneklem sayısı" ilkesini gerektirmemektedir (Miller, 1977). Homojen dağılmayan veriler için kullanılan Tamhane testinin hücre boyutlarının eşit olmadığı veya varyansların homojenliğinin ihlal edildiği durumlarda, Tukey'in HSD'sinden daha uygun olduğu düşünülür. Tamhane's istatistikleri, sadece "student $t$ " tabanında yürütülen bir test olup, tutucu ve dikkatli karşılaştırmalar yapması ile göze çarpmaktadır (Hochberg ve Tamhane, 1987).

Daha sonra nitel kısımda; görüşmeden elde edilen veriler betimsel analiz yaklaşımı kullanılarak analiz edilmiştir. Görüşme soruları analiz edilirken araştırmanın nicel boyutunda kullanılan ölçekteki boyut ve alt boyutlar tema olarak kullanılmıştır. Nitel kısımdaki verilerin analizine başlanmadan önce araştırmacının temaları ne kadar doğru ve tutarlı kodladığını tespit etmek amacıyla kodlama 
güvenirliğine ilişkin çalışma yapılmışır (Jackson, 2004; Einstein, 2005; Sloan, 2014; Syed ve Nelson, 2015). Bu amaç doğrultusunda görüşmeden elde edilen veriler arasında örneklem seçilmiş ve bir hafta arayla araştırmacı tarafından kodlama-tekrar kodlama yapılmıştır. Görüşme incelemesinde bir hafta arayla yapılan iki kodlama arasındaki tutarlılık \%95 olarak tespit edilmiştir. Araştırmacının kendi kodlama tutarlıı̆̆ının güvenirlik kat sayısının yüksek olduğu (Şencan, 2005; Li, Deng, Cai, Franks ve Yao, 2018) tespit edilmiş ve kodlama güvenilir olduğu belirlenmiştir. Bu sayede araştırmanın nicel ve nitel boyutundaki veriler aynı başıklar altında toplanarak daha bütüncül bir yaklaşım elde edilmiştir. Görüşme sorularından elde edilen veriler önceden belirlenen temalar kullanılarak betimsel analize tabi tutulmuştur. Öğrenci görüşlerinden doğrudan alıntılar yapılarak ulaşılan temalar desteklenmiştir. Bu şekilde iç ve dış tutarlıık çalışması gerçekleştirilmiştir.

\section{Uygulama Süreci}

Etkinlikler yıllık öğretim planı göz önünde bulundurularak 10 hafta boyunca uygulanmak üzere hazırlanmıştır. Etkinlikler her hafta bir adet uygulanmıştır. Her öğrenci bireysel olarak bu etkinliği gerçekleştirmiştir. Öğretmen her hafta konuyu anlatmıştır ve ardından öğrencilere ÖAY etkinliği görevini vermiştir. Ertesi hafta başında ise bu etkinlikleri toplamış ve gerekli dönütleri vermiştir. Araştırmacı ve ders öğretmeni tarafından meydana getirilen yıllık plan göz önünde bulundurularak uygulama takvimi hazırlanmıştır. Bu takvime göre ders yılının başladığı ilk haftada 19.09.2018 tarihinde ön test uygulaması gerçekleştirilmiştir. Ön test uygulamasının ardından hazırlanan uygulama takvimine uygun olarak deneysel uygulama gerçekleştirilmiştir. DG1 öğrencilerine ÖAY etkinliği, DG2 öğrencilerine ÖAY ve Dönüt (ÖAY+D), öğrencilerine ise Geleneksel Yöntem (GY) ile öğretim gerçekleştirilmiştir. Uygulanan deneysel uygulamaya ilişkin bilgiler Tablo 3'te sunulmuştur.

\section{Tablo 3.}

Uygulama Basamakları

\begin{tabular}{lllll}
\hline Hafta & Konu & DG1 & DG2 & KG \\
\hline 1 & MSÖ & Ön Test & Ön Test & Ön Test \\
2 & Introduce yourself & ÖAY & ÖAY + D & GY \\
3 & Nationality & ÖAY & ÖAY + D & GY \\
4 & Family & ÖAY & ÖAY + D & GY \\
5 & Occupations & ÖAY & ÖAY + D & GY \\
6 & Birthday & ÖAY & ÖAY + D & GY \\
7 & What time is it? & ÖAY & ÖAY + D & GY \\
8 & Wh- Questions & ÖAY & ÖAY + D & GY \\
9 & Daily Routines & ÖAY & ÖAY + D & GY \\
10 & Simple Present Tense & ÖAY & ÖAY + D & GY \\
11 & Present Continuous Tense & ÖAY & ÖAY + D & GY \\
12 & MSÖ & Son Test & Son Test & Son Test \\
13 & Görüşme & Görüşme & Görüşme & - \\
\hline
\end{tabular}

Tablo 3'te gösterildiği gibi araştırmanın uygulama safhasının on üç hafta sürdüğü, bu sürenin üç haftasının $(\% 23,07)$ ön test, son test ve görüşme uygulamalarına on haftasının $(\% 76,93)$ ise ÖAY etkinlik yazma uygulamasına ayrılmıştır. Ders öğretmeni konuları haftalık olarak işlemektedir. Tabloda her hafta hangi konunun ağırlıklı olarak öğretildiği belirtilmiştir. Öğretmen MEB müfredatına uygun olarak dersi işlemiştir, kontrol grubundan farklı olarak deney gruplarında ÖAY etkinliğini ödev olarak vermektedir. Ödev olarak ÖAY etkinliğini yapan öğrenciler bir sonraki haftanın ilk dersi bu ödevlerini öğretmenlerine teslim etmişlerdir. Kontrol grubu öğrencileri ise MEB müfredatında yer alan etkinlik ve uygulamaları yapmışlardır. DG1'de yer alan öğrenciler ödevlerini teslim ettikten sonra öğretmen etkinlikleri kontrol etmiş ve sınıfa hitaben daha iyi nasıl hazırlayabileceklerine dair genel ifadeler kullanarak değerlendirmede bulunmuştur. DG2'de yer alan öğrenciler ödevlerini teslim ettikten sonra öğretmen 
ödevleri değerlendirip her bir öğrenciye özgü güdülenme ve öğrenme stratejilerine uygun dönütler vermiştir. Araştırmanın ilk üç haftasında öğrencilerin etkinliğe alışabilmeleri için etkinlik haftanın son ders saatinde sınıf içi etkinlik olarak yapılmışken son yedi haftası sınıf dışı etkinlik olarak öğrencilerin evlerinde yapılmıştır. Illk üç haftada öğrenciler etkinlikle ilgili sorularını öğretmene sormuş ve etkinliklerini tamamlayarak o ders saatinin sonunda öğretmene teslim etmişlerdir. Bu etkinlik için kırk dakikalık dersin yirmi dakikası yeterli olmuştur. Üç hafta sonunda öğrencilerin etkinliğe tamamen alıştıkları gözlemlenmiş ve sınıf dışı etkinlik olarak yapmaları araştırmacı ve öğretmen tarafından uygun görülmüştür. Öğretmen ve araştırmacı tarafından yapılan gözlemde öğrencilerin dördüncü haftadan sonra yeni konu anlatımı yapılırken etkinlik için hazırlık yaptıkları tespit edilmiştir. Öğretmen yeni bir konuya geçtiğini söyleyip yeni konuyu anlattığı derslerin sonunda öğrencilerin bir kısmı ders aralarında öğretmene yapmayı planladıkları etkinlik hakkında sorular sormuştur. Öğrencilerden bazılarının ise yapmayı planladıkları etkinlikleri ders aralarında tasarladıkları, yazıp, çizdikleri gözlenmiş̧ir.

Bu etkinlikler iki adet 9. sınıftan ( $\mathrm{N}: 61$ ) elde edilmiştir. Öğrenciler on hafta boyunca bu etkinlikleri hazırlamışlardır ( $\mathrm{N}: 610$ ). Mazeretleri sebebiyle (hastalık, ailevi sebepler vb.) etkinliği zamanında teslim edemeyen öğrencilerden geldikleri hafta etkinlik alınmışır. Bazı öğrencilerin etkinlikleri bir sayfadan fazla olduğu için etkinliklerin toplam sayfa sayısı 633'tür.

\section{Bulgular ve Yorum}

\section{Birinci Alt Probleme ilişkin Bulgular ve Yorum}

GS düzeltilmiş son test puanlarına göre yapılan testlerden elde edilen bulgular ve yorumlar aşă̆ıda sunulmuştur. Güdü son testine ait betimsel istatistikler Tablo $4^{\prime}$ te sunulmuştur.

Tablo 4.

GS Son-testine Ait Betimsel Istatistikler

\begin{tabular}{llllll}
\hline Ölçek & Grup & $\mathbf{N}$ & $\overline{\mathbf{X}}$ & sd & Düzeltilmiş \\
\hline \multirow{4}{*}{ Güdü } & DG1 & 31 & 4.81 & .48 & $4.78^{\mathrm{a}}$ \\
& DG2 & 30 & 5.40 & .27 & $5.39^{\mathrm{a}}$ \\
& KG & 30 & 4.43 & .61 & $4.43^{\mathrm{a}}$ \\
& Toplam & 91 & 4.88 & .62 & \\
\hline
\end{tabular}

Tablo 4'te Güdü boyutuna ait düzeltilmiş son test puanlarına göre en fazla puandan en az puana doğru sıralamanın DG2 ( $\bar{X}: 5.39)$, DG1 ( $\mathrm{X}: 4.78)$, KG ( $\bar{X}: 4.43)$ şeklinde olduğu tespit edilmiştir. Gruplar arasındaki puan farkılıklarının anlamlı olup olmadığını tespit etmek amacıyla uygulanan ANCOVA testi sonuçları Tablo 5'te sunulmuştur.

Tablo 5.

GS Son-test ANCOVA Sonuçları

\begin{tabular}{llllll}
\hline $\begin{array}{l}\text { Varyansın } \\
\text { Kaynağı }\end{array}$ & $\begin{array}{l}\text { Kareler } \\
\text { toplamı }\end{array}$ & sd & $\begin{array}{l}\text { Kareler } \\
\text { ortalaması }\end{array}$ & $\mathbf{f}$ & $\mathbf{P}$ \\
\hline Ön test & 1.24 & 1 & 1.24 & 6.74 & .01 \\
Grup & 5.04 & 2 & 2.52 & 13.61 & .00 \\
Hata & 15.74 & 85 & .18 & & \\
Toplam & 2202.27 & 91 & & & \\
\hline
\end{tabular}

Tablo 5'te elde edilen ANCOVA sonuçlarına göre, grupların ön test puanlarına göre düzeltilmiş son test puanları arasında $\left(F_{(2,85)}=13.61 ; p<.05\right)$ anlamlı bir farkın oluştuğu görülmüştür. Ortaya çıkan anlamlı farklılığın hangi gruplar lehine olduğunu tespit etmek için yapılan Bonferroni testi Tablo $6^{\prime}$ da sunulmuştur. 
Tablo 6.

Güdü Boyutuna Ait Bonferroni Testi Sonuçları

\begin{tabular}{lllll}
\hline Boyut & Gruplar & Ortalama Farkı & Standart Hata & P \\
\hline \multirow{2}{*}{ Güdü } & DG2-DG1 & $.61^{*}$ & .11 & .00 \\
& DG2-KG & $.96^{*}$ & .11 & .00 \\
\hline
\end{tabular}

Tablo 6'daki sonuçlara göre DG2 ve DG1 arasında ( $p<.05)$ DG2 lehine; DG2 ve KG arasında $(p<.05)$ DG2 lehine; DG1 ve KG arasında $(p<.05)$ DG1 lehine anlamlı bir farkın oluştuğu görülmüştür. Bu sonuçlara göre uygulanan deneysel yöntemin deney grupları lehine güdülenme üzerinde anlamlı bir farklılık meydana getirdiği yorumu yapılabilir. GSÖ’ye ait değer alt boyutu ve alt faktörlerine ilişkin betimsel tespitler Tablo 7'de sunulmuştur.

Tablo 7.

Değer Alt Boyutuna Ait Betimsel Analiz Sonuçları

\begin{tabular}{|c|c|c|c|c|c|c|}
\hline Alt Boyut & Alt Faktör & Grup & $\mathbf{N}$ & $\overline{\mathbf{x}}$ & sd & Düzeltilmiş Ortalama \\
\hline \multirow{16}{*}{ Değer } & & DG1 & 31 & 5.22 & .57 & $5.20^{\mathrm{a}}$ \\
\hline & & DG2 & 30 & 5.29 & .43 & $5.27^{\mathrm{a}}$ \\
\hline & & KG & 30 & 4.454 & .78 & $4.32^{\mathrm{a}}$ \\
\hline & & Toplam & 91 & 4.99 & .71 & \\
\hline & \multirow{4}{*}{ İçsel Hedef } & DG1 & 31 & 5.26 & .83 & $5.27^{\mathrm{a}}$ \\
\hline & & DG2 & 30 & 5.23 & .70 & $5.31^{\mathrm{a}}$ \\
\hline & & KG & 30 & 4.22 & .90 & $4.03^{a}$ \\
\hline & & Toplam & 91 & 4.91 & .94 & \\
\hline & \multirow{4}{*}{ Dışsal Hedef } & DG1 & 31 & 5.26 & .834 & $5.16^{\mathrm{a}}$ \\
\hline & & $\mathrm{DG} 2$ & 30 & 5.23 & .70 & $5.41^{a}$ \\
\hline & & KG & 30 & 4.22 & .90 & $4.15^{\mathrm{a}}$ \\
\hline & & Toplam & 91 & 4.91 & .94 & \\
\hline & \multirow{4}{*}{ Görev Değeri } & DG1 & 31 & 5.00 & .74 & $5.04^{a}$ \\
\hline & & DG2 & 30 & 5.15 & .68 & $5.09^{a}$ \\
\hline & & KG & 30 & 4.36 & 1.20 & $4.11^{a}$ \\
\hline & & Toplam & 91 & 4.84 & .95 & \\
\hline
\end{tabular}

Tablo 7'deki Değer alt boyutuna ait düzeltilmiş son test puanlarına göre en fazla puandan en az

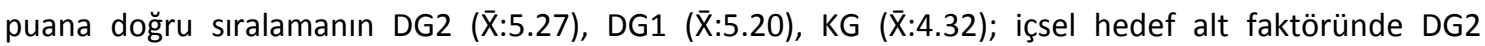

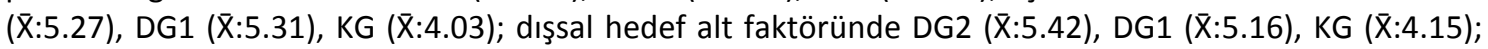

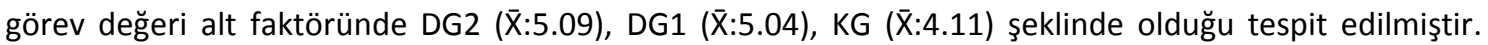
Gruplar arasındaki puan farklılıklarının anlamlı olup olmadığını tespit etmek amacıyla uygulanan ANCOVA testi sonuçları Tablo 8'de sunulmuştur. 
Tablo 8.

Değer Alt Boyutu ANCOVA Sonuçları

\begin{tabular}{|c|c|c|c|c|c|c|c|}
\hline Alt boyut & Alt Faktör & $\begin{array}{l}\text { Varyansın } \\
\text { Kaynağı }\end{array}$ & $\begin{array}{l}\text { Kareler } \\
\text { toplamı }\end{array}$ & sd & $\begin{array}{l}\text { Kareler } \\
\text { ortalaması }\end{array}$ & F & $\mathbf{P}$ \\
\hline \multirow{16}{*}{ Değer } & & Ön test & 4.49 & 1 & 4.49 & 14.96 & .00 \\
\hline & & Grup & 5.97 & 2 & 2.99 & 9.95 & .00 \\
\hline & & Hata & 25.51 & 85 & .30 & & \\
\hline & & Toplam & 2314.09 & 91 & & & \\
\hline & \multirow{4}{*}{$\begin{array}{l}\text { İçsel } \\
\text { hedef }\end{array}$} & Ön test & 15.28 & 1 & 15.28 & 31.52 & .00 \\
\hline & & Grup & 6.40 & 2 & 3.20 & 6.60 & .00 \\
\hline & & Hata & 41.21 & 85 & .48 & & \\
\hline & & Toplam & 2275.75 & 91 & & & \\
\hline & \multirow{4}{*}{$\begin{array}{l}\text { Dişsal } \\
\text { hedef }\end{array}$} & Ön test & 5.42 & 1 & 5.42 & 8.81 & .00 \\
\hline & & Grup & 24.90 & 2 & 12.45 & 20.25 & .00 \\
\hline & & Hata & 53.48 & 87 & .61 & & \\
\hline & & Toplam & 2275.75 & 91 & & & \\
\hline & \multirow{4}{*}{$\begin{array}{l}\text { Görev } \\
\text { değeri }\end{array}$} & Ön test & 9.80 & 1 & 9.80 & 20.34 & .00 \\
\hline & & Grup & 28.84 & 2 & 14.42 & 29.93 & .00 \\
\hline & & Hata & 40.95 & 85 & .48 & & \\
\hline & & Toplam & 2215.19 & 91 & & & \\
\hline
\end{tabular}

Tablo 8'deki ANCOVA sonuçlarına göre, grupların ön test puanlarına göre düzeltilmiş son test puanları arasında Değer alt boyutunda $\left(F_{(2,85)}=9.95 ; p<.05\right)$; İçsel hedef alt faktöründe $\left(F_{(2,85}\right)=6.60$; $p<.05)$; Dışsal hedef alt faktöründe $\left(F_{(2,85)}=20.25 ; p<.05\right)$; görev değeri alt boyutunda $\left(F_{(2,85)}=29.93\right.$; $\mathrm{p}<.05)$ grupların almış olduğu puanlar arasında anlamlı farklılık vardır. Ortaya çıkan anlamlı farklılıkların hangi gruplar lehine olduğunu tespit etmek için yapılan Bonferroni testi Tablo 9'da sunulmuştur.

Tablo 9.

Değer Alt Boyutuna Ait Bonferroni Sonuçları

\begin{tabular}{|c|c|c|c|c|c|}
\hline Alt Boyut & Alt faktör & Gruplar & Ortalama Farkı & Standart Hata & $\mathbf{P}$ \\
\hline \multirow{12}{*}{ Değer } & & DG2-DG1 & .06 & .14 & .95 \\
\hline & & DG2-KG & $.94 *$ & .15 & .00 \\
\hline & & DG1-KG & $.87^{*}$ & .14 & .00 \\
\hline & \multirow{3}{*}{ İçsel hedef } & DG2-DG1 & .03 & .18 & .96 \\
\hline & & DG2-KG & $1.27^{*}$ & .18 & .00 \\
\hline & & DG1-KG & $1.23^{*}$ & .18 & .00 \\
\hline & \multirow{3}{*}{ Dışsal hedef } & DG2-DG1 & .26 & .22 & .74 \\
\hline & & DG2-KG & $1.26^{*}$ & .22 & .00 \\
\hline & & DG1-KG & $1.00 *$ & .20 & .00 \\
\hline & \multirow{3}{*}{ Görev değeri } & DG2-DG1 & .05 & .18 & 1.00 \\
\hline & & DG2-KG & $.98 *$ & .18 & .00 \\
\hline & & DG1-KG & $.92^{*}$ & .18 & .00 \\
\hline
\end{tabular}

Tablo 9'daki sonuçlara göre, değer alt boyutunda DG2 ile KG arasında DG2 ( $p<.05)$ lehine, DG1 ile KG arasında DG1 $(p<.05)$ lehine; İçsel hedef alt faktöründe DG2 ile KG arasında DG2 $(p<.05)$ lehine, DG1 ile KG arasında DG1 $(p<.05)$ lehine; Dışsal hedef alt faktöründe DG2 ile KG arasında DG2 ( $p<.05)$ lehine, DG1 ile KG arasında DG1 ( $p<.05)$ lehine Görev değeri alt faktöründe DG2 ile KG arasında DG2 $(p<.05)$ lehine, DG1 ile KG arasında DG1 $(p<.05)$ lehine istatistikî olarak anlamlı farklılık vardır. Bu sonuçlara göre deney gruplarına uygulanan ÖAY etkinliğinin öğrencilerin değer, içsel hedef belirleme, dışsal hedef belirleme ve görev değeri güdülerini sağlamada kontrol grubu öğrencilerine göre daha etkili olmalarını sağladığı yorumu yapılabilir. GSÖ’nün bir diğer alt boyutu olan beklenti alt boyutuna dair yapılan 
analizler aşağıda sunulmuştur. Beklenti alt boyutuna ait betimsel analiz sonuçları Tablo 10 'da sunulmuştur.

Tablo 10.

Beklenti Alt Boyutuna Ait Betimsel Analiz Sonuçları

\begin{tabular}{|c|c|c|c|c|c|c|}
\hline Alt Boyut & Alt Faktör & Grup & $\mathbf{N}$ & $\overline{\mathbf{X}}$ & sd & Düzeltilmiş Ortalama \\
\hline \multirow{12}{*}{ Beklenti } & & DG1 & 31 & 5.02 & .72 & $5.10 a$ \\
\hline & & DG2 & 30 & 5.30 & .28 & $5.28 a$ \\
\hline & & KG & 30 & 4.55 & .75 & $4.29 a$ \\
\hline & & Toplam & 91 & 4.96 & .69 & \\
\hline & \multirow{4}{*}{$\begin{array}{l}\text { Öz Yeterlilik } \\
\text { Algısı }\end{array}$} & DG1 & 31 & 4.90 & .80 & $5.03 a$ \\
\hline & & DG2 & 30 & 5.39 & .42 & $5.36 a$ \\
\hline & & KG & 30 & 4.55 & .80 & $4.26 a$ \\
\hline & & Toplam & 91 & 4.95 & .77 & \\
\hline & \multirow{4}{*}{$\begin{array}{l}\text { Öğrenme } \\
\text { Kontrolü } \\
\text { İhtiyacı }\end{array}$} & DG1 & 31 & 5.46 & .93 & $5.47 a$ \\
\hline & & DG2 & 30 & 5.12 & .50 & $5.14 a$ \\
\hline & & KG & 30 & 4.53 & 1.05 & $4.35 a$ \\
\hline & & Toplam & 91 & 5.04 & .93 & \\
\hline
\end{tabular}

Tablo 10'daki Beklenti alt boyutuna ait düzeltilmiş son test puanlarına göre en fazla puandan en az

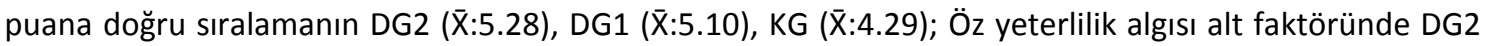

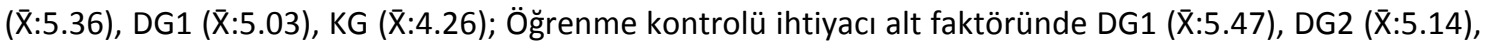
KG (X:4.35) şeklinde olduğu tespit edilmiştir. Gruplar arasındaki puan farklılıklarının anlamlı olup olmadığını tespit etmek amacıyla uygulanan ANCOVA testi sonuçları Tablo 11'de sunulmuştur.

Tablo 11.

Beklenti Alt Boyutu ANCOVA Sonuçları

\begin{tabular}{|c|c|c|c|c|c|c|c|}
\hline Alt boyut & Alt Faktör & $\begin{array}{l}\text { Varyansın } \\
\text { Kaynağı }\end{array}$ & $\begin{array}{l}\text { Kareler } \\
\text { toplamı }\end{array}$ & sd & $\begin{array}{l}\text { Kareler } \\
\text { ortalaması }\end{array}$ & $\mathbf{F}$ & $\mathbf{P}$ \\
\hline \multirow{12}{*}{ Beklenti } & & Ön test & 6.90 & 1 & 6.90 & 26.33 & .00 \\
\hline & & Grup & 10.33 & 2 & 5.16 & 19.69 & .00 \\
\hline & & Hata & 22.30 & 85 & .26 & & \\
\hline & & Toplam & 2286.40 & 91 & & & \\
\hline & Öz & Ön test & 7.72 & 1 & 7.72 & 23.87 & .00 \\
\hline & Yeterlilik & Grup & 15.78 & 2 & 7.89 & 24.38 & .00 \\
\hline & AlgISI & Hata & 27.50 & 85 & .32 & & \\
\hline & & Toplam & 2285.73 & 91 & & & \\
\hline & Öğrenme & Ön test & 12.36 & 1 & 12.36 & 21.07 & .00 \\
\hline & Kontrolü & Grup & 7.85 & 2 & 3.92 & 6.69 & .00 \\
\hline & İhtiyacı & Hata & 49.87 & 85 & .58 & & \\
\hline & & Toplam & 2397.06 & 91 & & & \\
\hline
\end{tabular}

Tablo 11'deki sonuçlara göre grupların ön test puanlarına göre düzeltilmiş son test puanları arasında Beklenti alt boyutunda $\left(F_{(2,85)}=19.69 ; p<.05\right)$; Öz yeterlilik algısı alt faktöründe $\left(F_{(2.85)}=24.38 ; p<.05\right)$; Öğrenme kontrolü ihtiyacı alt boyutunda $\left(\mathrm{F}_{(2,85)}=6.69 ; \mathrm{p}<.05\right)$ grupların almış olduğu puanlar arasında anlamlı farklııı vardır. Ortaya çıkan anlamlı farkıııkların hangi gruplar lehine olduğunu tespit etmek için yapılan Bonferroni testi Tablo 12'de sunulmuştur. 
Tablo 12.

Beklenti Alt Boyutuna Ait Bonferroni Sonuçları

\begin{tabular}{llllll}
\hline Alt Boyut & Alt faktör & Gruplar & $\begin{array}{l}\text { Ortalama } \\
\text { Farkı }\end{array}$ & $\begin{array}{l}\text { Standart } \\
\text { Hata }\end{array}$ & P \\
\hline \multirow{3}{*}{ Beklenti } & & DG2-DG1 & .18 & .13 & .55 \\
& & DG2-KG & $.98^{*}$ & .14 & .00 \\
& DG1-KG & $.80^{*}$ & .14 & .00 \\
\cline { 2 - 6 } & Öz yeterlilik & DG2-DG1 & .33 & .15 & .09 \\
& algıSI & DG2-KG & $1.09^{*}$ & .16 & .00 \\
& DG1-KG & $.76^{*}$ & .16 & .00 \\
\cline { 2 - 5 } & Öğrenme & DG2-DG1 & -.33 & .19 & .30 \\
kontrolü & DG2-KG & $.78^{*}$ & .21 & .00 \\
& ihtiyacı & DG1-KG & $1.11^{*}$ & .20 & .00 \\
\hline
\end{tabular}

Tablo 12'deki sonuçlara göre beklenti alt boyutunda DG2 ile KG arasında DG2 ( $p<.05)$ lehine, DG1 ile KG arasında DG1 ( $p<.05)$ lehine; Öz yeterlilik algısı alt faktöründe DG2 ile KG arasında DG2 ( $p<.05)$ lehine, DG1 ile KG arasında DG1 $(p<.05)$ lehine; Öğrenme kontrolü intiyacı alt faktöründe DG2 ile KG arasında DG2 $(p<.05)$ lehine, DG1 ile KG arasında DG1 $(p<.05)$ lehine istatistikî olarak anlamlı farklılık tespit edilmiştir. Bu sonuçlara göre deney gruplarına uygulanan ÖAY etkinliğinin öğrencilerin beklenti, öz yeterlilik algısı ve öğrenme kontrolü ihtiyacı güdülerinde kontrol grubu öğrencilerine göre daha etkili olmalarını sağladığı yorumu yapılabilir. GSÖ’nün diğer alt boyutu olan Duyuşsal alt boyutuna ait sınav kaygısı alt faktörüne ilişkin yapılan analizler aşağıda sunulmuştur. Duyuşsal alt boyuta ait betimsel analiz sonuçları Tablo 13'te verilmiştir.

Tablo 13.

Duyuşsal Alt Boyuta Ait Betimsel Istatistikler

\begin{tabular}{lllllll}
\hline Alt Boyut & $\begin{array}{l}\text { Alt } \\
\text { Faktör }\end{array}$ & Grup & $\mathbf{N}$ & $\overline{\mathbf{X}}$ & sd & $\begin{array}{l}\text { Düzeltilmiş } \\
\text { Ortalama }\end{array}$ \\
\hline \multirow{3}{*}{ Duyuşsal } & Sınav & DG1 & 31 & 4.84 & .92 & $4.88 \mathrm{a}$ \\
& KaygısI & KG & 30 & 4.32 & 1.08 & $4.37 a$ \\
& & 30 & 4.07 & .77 & $4.00 \mathrm{a}$ \\
\hline
\end{tabular}

Tablo 13'teki Sınav Kaygısı alt faktörüne ait düzeltilmiş son test puanlarına göre en fazla puandan en az puana doğru sıralamanın DG1 ( $\mathrm{X}: 4.88)$, DG2 (X:4.37), KG ( $\bar{X}: 4.00)$ şeklinde olduğu tespit edilmiştir. Gruplar arasındaki puan farklılıklarının anlamlı olup olmadığını tespit etmek amacıyla uygulanan ANCOVA testi sonuçları Tablo 14 'te sunulmuştur.

Tablo 14.

Duyuşsal Alt Boyut ANCOVA Sonuçları

\begin{tabular}{llllll}
\hline $\begin{array}{l}\text { Varyansın } \\
\text { Kaynağı }\end{array}$ & $\begin{array}{l}\text { Kareler } \\
\text { toplamı }\end{array}$ & Sd & $\begin{array}{l}\text { Kareler } \\
\text { ortalaması }\end{array}$ & $\mathbf{F}$ & $\mathbf{P}$ \\
\hline Ön test & 2.24 & 1 & 2.24 & 2.59 & .11 \\
Grup & 11.21 & 2 & 5.61 & 6.47 & .00 \\
Hata & 75.32 & 87 & .86 & & \\
Toplam & 1864.68 & 91 & & & \\
\hline
\end{tabular}

Tablo 14'teki sonuçlara göre grupların ön test puanlarına göre düzeltilmiş son test puanları arasında $\left(F_{(2,87)}=6.47 ; p<.05\right)$ anlamlı farklıık vardır. Ortaya çıkan anlamlı farklılığın hangi gruplar lehine olduğunu tespit etmek için yapılan Bonferroni testi Tablo 15'te sunulmuştur. 
Tablo 15.

Duyuşsal Alt Boyutuna Ait Bonferroni Testi Sonuçları

\begin{tabular}{llllll}
\hline Alt Boyut & Alt faktör & Gruplar & $\begin{array}{l}\text { Ortalama } \\
\text { Farkı }\end{array}$ & Standart Hata & P \\
\hline \multirow{2}{*}{ Duyuşsal } & \multirow{2}{*}{ Sınav kaygısI } & DG2-DG1 & -.51 & .23 & .10 \\
& & DG2-KG & .37 & .25 & .43 \\
& & DG1-KG & $.88^{*}$ & .24 & .00 \\
\hline
\end{tabular}

Tablo 15'teki sonuçlara göre DG1 ve KG arasında ( $p<.05)$ DG1 lehine anlamlı farklılık vardır. Bu sonuçlara göre uygulanan deneysel yöntemin Sınav kaygısı üzerinde anlamlı bir farklılık meydana getirmede etkisiz olduğu yorumu yapılabilir. ÖAY etkinliğinin güdülenme stratejilerinde deney grupları ve KG arasında istatistikî olarak anlamlı bir farklılık meydana getirdiği ve bu farklılığın sınav kaygıSı alt faktörü dışında her iki deney grubu lehine olmasında etkili olduğu yorumu yapılabilir.

\section{İkinci Alt Probleme ilişkin Bulgular ve Yorum}

\section{Güdülenmeye ilişkin öğrenci görüşleri}

Bu kısımda güdü ana temasının alt temaları olan "değer, beklenti ve duyuşsal”a ve bu üç alt temanın içinde yer alan alt temalara ilişkin yapılan tespitlere yer verilmiştir. Öğrencilere ilk olarak yapılan etkinliklerin derse karşı olan ilgilerini nasıl etkilediği sorulmuştur. Öğrencilerden beşi (N:5; Ö1, Ö2, Ö3, Ö5, Ö6: \%83.33) ilgilerini artırdığını ifade etmiştir. Ayrıca öğrenciler dersin kolaylaştığını, kendilerini ifade edebildiklerini, dersin öğretmeninden yardım alma durumlarının arttığını ifade etmişlerdir. Güdülenme ana temasına ilişkin yapılan tespitler aşağıdaki Tablo 16'da gösterilmektedir.

Tablo 16.

Güdülenmeye iliş̧kin Betimsel Sonuçlar

\begin{tabular}{llll}
\hline Alt temalar & Kodlar & N & f (\%) \\
\hline \multirow{4}{*}{ Değer } & Illgi çekici (ilginin artması, merak) & 5 & 83 \\
& Önem (değerli, kullanabilme) & 6 & 100 \\
& Daha iyi olma durumu & 5 & 83 \\
& Anlamlı hale gelme & 4 & 67 \\
& Faydalı olma durumu & 6 & 100 \\
\hline \multirow{5}{*}{ Beklenti } & Inancın artma durumu & 5 & 83 \\
& Daha iyi olma durumu (başarı) & 5 & 83 \\
& Kolaylaşma & 6 & 100 \\
& Öz güven-Öz yeterlilik & 5 & 83 \\
& Öz değerlendirme (olumlu ifadeler) & 4 & 67 \\
\hline \multirow{5}{*}{ Duyuşsal } & Sevme & 6 & 100 \\
& Yeterli olma & 5 & 83 \\
& Kaygı (endişe, heyecan) & 1 & 17 \\
& Moral bozukluğu & 0 & 0 \\
\hline
\end{tabular}

Öğrencilerin Güdülenme ana temasına ilişkin kullandıkları ifadelerin alt temalara uyumunu gösteren tablo 16 'da ifadelerin ne sıklıkta kullanıldıkları belirtilmiştir. Elde edilen bulgularda en sık (N:6; $\mathrm{f}: \% 100)$ değerli, faydalı, kolaylaşma ve sevme ifadelerinin yer aldığı tespit edilmiştir. Bununla birlikte moral bozukluğu ( $\mathrm{N}: 1 ; \mathrm{f}: \% 17$ ) ve kaygı (endişe, heyecan) (N:0; f:\%0) ifadelerinin en az sıklıkta kullanılan ifadeler olduğu saptanmıştır. Tespit edilen temalara ilişkin öğrenci görüşlerinden yapılan doğrudan alıntılar aşağıda yer almaktadır:

...aslında en başta biraz garipsemiştim. Yani tam olarak nasıl olacağını anlayamamıştım ama yaptıkça anlamaya başladım. Diğer okullardaki arkadaşlarımla görüştüğümde onlara sordum mesela onlar böyle şeyler yapmıyorlarmış. Farklı geldi, ilk hafta biraz karışıktı. Asında etkinlik kolaydı ama benim ne hissettiğim konusu karışıtı. 
Sonra yapmaya başladıkça faydalı olduğunu gördüm. Mesela etkinlikten sonraki derste daha önceki dersi hatırlamakta zorlanırdım ama şekiller falan gözümün önüne gelince daha kolay hatırlamaya başladım. Ders daha kolay ve ilgi çekici hale geldi... (Ö1)

Ö1 kodlu öğrencinin kullanmış olduğu ifadelerde geçen "farkl, faydalı, kolaylaştırma, hatırlama, akranlarla görüşme, ilgi çekici" ifadeleri öğrencinin derse değer verdiği ve güdülenmesinin arttığını göstermektedir. Etkinliğin önceleri karışık gelmesi ve daha sonra faydasını gördükçe anlamlı bulması ve sevmesi öğrencinin yeni duruma uyum sağlaması, bu durumu olumlu duygularla birleştirmesi aynı zamanda onun eleştirel düşünme stratejisi kullandığını göstermektedir. Şekillere benzeterek hatırlaması, bilgileri kodlama yaparak öğrenme gerçekleştirdiği ve dolayısıyla açımlama stratejisini kullandığını göstermektedir. Öğrencinin ÖAY etkinliğini yaptıkça faydasını gördüğü ve bu etkinliğin derse karşı ilgisini artırdığı yorumu yapılabilir. Ö6 kodlu öğrenciden yapılan doğrudan alıntı şöyledir:

...hocam benim ingilizcem pek iyi değil. Ortaokulda da çok iyi değildi. Şimdi biraz ortaokuldaki gibi değilim. Liseye geldiğim için büyüdüm, daha iyi olacağım. Ingilizce yine aynı olur demiştim. Bu etkinliği Türkçe olarak da yapabilirsiniz dedi hoca. O zaman tabi yaparım dedim (dediydim). Daha da değişik şeyler çizdim yani modifiyeli araba gibi mesela, TOFAŞ. Bundan başka... Anlamadığım olunca hocaya Türkçe de sorunca daha kolay oluyor. ingilizce soramıyordum ama şimdi anlayınca soru sormaya başladım, hoca da dedi, beğendi yani...(Ö6)

Ö6 kodlu öğrencinin kullanmış olduğu ifadelerde geçen "daha iyi olacağım" ifadesi öğrencinin performansına dair inancını göstermektedir. Öğrencinin öz yeterlilik algınsın geliştiği ifade edilebilir. Çünkü öğrenci daha önceki öğrenme yaşantısında bu dersten başarılı olmadığını ifade etmektedir. Ayrıca etkinlikte Türkçe kullanmanın serbest olmasının öğrencinin bu durumuna olumlu bir katkı yaptığı yorumu yapılabilir. Öğrencinin "...şimdi anlayınca.." ifadesi onun öğrenmesinde bir farkındalık meydana geldiği ve "...soru sormaya başladım..." ifadesi ise öğrencinin derse karşı güdülendiği, ayrıca bu güdülenmeyi sürdürmeyi başardığını göstermektedir. Öğrencinin ders performansında, ilgisinde ve inancında olumlu değişiklikler meydana geldiği ifade edilebilir. Bu durumun öğrencinin güdülenmesine olumlu katkı yaptı̆̆ı yorumu yapılabilir.

Öğrencilere ikinci olarak ÖAY etkinliklerinin onların sınava karşı olan duygularını nasıl etkilediği sorulmuştur. Öğrencilerin tamamı (6: Ö1, Ö2, Ö3, Ö4, Ö5, Ö6: \%100) etkinliklerin notlarına olumlu etkisi olduğunu ifade etmiştir. ÖAY etkinliğinin öğrencilerin sınav kaygılarını azalttığı ifade edilebilir. Öğrencilerin dördü (4: Ö1, Ö2,Ö3;Ö5: \%66,66) sınav korkusunun tamamen ortadan kalktığını ifade ederken ikisi $(2$ : Ö4,Ö6 \%33,33) korkunun yerini heyecan duygusunun aldığını ifade etmişlerdir. Bu durum öğrencilerin duyuşsal boyuta ait geliştirdiği duyguları ortaya koymaktadır. Ayrıca olumlu görüş belirten öğrencilerin etkinliklerde kendi yaşamlarından, tecrübelerinden istifade ederek içeriği belirlemelerinin bu duruma katkısı olduğu ifade edilebilir. Tespit edilen temalar ve ilgili öğrenci görüşleri aşağıda yer almaktadır:

...derste ve etkinlikte yaptığımız konular çıkıyor. Etkinlikleri kendimize göre yaptığımız için akılda kalıyor bu şekilde sınav da kolay geçiyor. Korkuyorum diyemem... (Ö1)

Ö1 kodlu öğrencinin derste yaptığı konuların çıktı̆ı̆ıı ifade etmesi; derse ilgisinin olduğu, bu derste öğrendiği, öğrendiği bilgileri hatırladığı ve bu hatırlamadan dolayı sınav kaygısının ortadan kalktığı şeklinde yorumlanabilir.

$$
\text { ...notlarıma kesinlikle olumlu yansıdı... (Ö2) }
$$

Ö2 kodlu öğrenci bu konudaki ifadesinde net bir cevap vererek "kesin" kelimesini kullanmıştır. Bu durumun kaygıyı azalttığı ve beklentiyi geliştirdiği ifade edilebilir.

...etkisi bence çok güzel, çünkü yükseldi... (Ö5) 
...eskiden çok anlamazdım sınavda da sıkılırdım. Şimdi daha öncesinde yazdık diye ve öncesinde hocaya sorduklarım aklıma gelince daha iyi not alıyorum. Kötüydü zaten daha önce notum... (Ö6)

Öğrencilerin ifadelerinde yer alan "olumlu yansıdı, olumlu, yükseldi, daha iyi not alma" ifadeleri, öğrencilerin performansa dair inançlarının ve ilgilerinin arttı̆̆ı, bu artışın onların güdülenmelerine katkı sağladığı ve duyuşsal olarak da olumlu duygular geliştirdiklerini göstermektedir. Sınav kaygısının azaldığı, sınavda sıkılmadığı ifadesinden de anlaşılabilir. ÖAY etkinliklerinin öğrencilerin sınav kaygılarını azalttığı yorumu yapılabilir.

Öğrencilerin beşi (5: Ö1, Ö2, Ö3, Ö4, Ö5: \%83,33) etkinliklerin bu dersten yüksek not alacağına dair inançlarına olumlu etkisi olduğunu ifade etmiştir. Öğrencilerin "beklenti" temasına dair görüşlerinin olumlu olduğu ifade edilebilir. Tespit edilen temalar ve ilgili öğrenci görüşleri aşağıda yer almaktadır:

...derste zaten anlamadıklarımı görmüş oldum, böyle olunca da yüksek not alacağımı düşündüm... (Ö1)

Ö1 kodlu öğrencinin etkinlikleri yaparken eksiklerini tespit edip onları giderdiği ve bu sayede verimli bir çalışma gerçekleştirdiği, bu çalışma sayesinde olumlu beklenti içerine girdiği bu durumun güdülenmesine katkı sağladığı yorumu yapılabilir.

$$
\text { “...ilk sınavdan beş alınca arttı tabi hocam..." (Ö3) }
$$

Ö3 kodlu öğrencinin sınavda başarılı olması onun derse karşı beklentisini yükseltmesine ve derse ilgisinin artmasına katkı sağlamıştır.

“...şuan girsem en az 90 alırım..."(Ö4)

Ö4 kodlu öğrencinin beklentisinin ve öz yeterlilik inancının yüksek olduğu ifade edilebilir.

“...inancım hep yüksekti ama sanki daha garanti gibi oldu diyebilirim..." (Ö5)

Ö5 kodlu öğrencinin beklentisinin etkinlikten önce de yüksek olduğu fakat bu etkinlikle birlikte öz yeterlilik inancının da arttığı ifade edilebilir. Bu durumun onun beklentisini daha inançlı bir hale getirmektedir. Bu durum onun güdülenmesine katkı sağlamaktadır yorumu yapılabilir.

Öğrencilerin beşi (5: Ö1, Ö2, Ö3, Ö5, Ö6: \%83,33) sınav için bu etkinliklerden başka hazırlık gerekmediğini belirtmiştir. Etkinliğin yeterliliği öğrencilerin performans inançlarının gelişimiyle ilgili fikir elde etmek kullanılmıştır. Ö2 ve Ö5 kodlu öğrencilerin görüşlerinden yapılan doğrudan alıntı aşağıda sunulmuştur:

...bence yeterli zaten hocamı da öyle dedi. Diğer ödevler de var. Onlara destek oluyor.

Bir de zaten dersten önce yapıyorum ödevi aklımda kalsın diye. Kısaca yeterli bence... (Ö2)

Ö2 kodlu öğrenci bu etkinliği diğer ödevlerle birlikte gerçekleştirdiğini ve dersten önce yaparak bir tekrar amacı güdüğünü bu şekilde kendi öğrenme süreci üzerinde kontrol sağladığı, hedeflerine yönelik düzenleme yaptığı ve etkinliği yeterli gördüğü ifade edilebilir.

...yeter hocam, soruları da görünce bu yaptığımız aklımıza geliyor daha kolay oluyor. isteyen yapabilir yani bakabilir başka kaynaklara da ama ben bakmadım. Bir de bunlar kendi yazdıklarım olduğu için kısa daha kolay anlamak...(Ö5)

Ö5 kodlu öğrencinin kendi öğrenmesini analiz ettiği ve ihtiyacına göre verilen etkinliği düzenlediği "Bir de bunlar kendi yazdıklarım olduğu için kısa daha kolay anlamak" ifadesinden anlaşılmaktadır. Bu etkinlikleri ders ve kendi hedeflerine giden yolda etkin bir araç haline dönüştürdüğü bu durumun hedef belirleme ve analiz yapma üstbiliş stratejilerini etkin bir biçimde kullanmasını sağladığı şeklinde yorumlanabilir.

Öğrencilerin görüşlerinden elde edilen verilerden ulaşılan temalar ve alt temalar ışığında "iç̧sel-dışsal hedef düzenleme, görev değeri, öz yeterlilik algıları, öğrenme kontrolü inançları, sınav kaygıları” 
temalarına ve "değer, beklenti ve duyuşsal" alt temalarına ilişkin görüşlerinin olumlu bir biçimde değiştiği, bu durumun da güdülenmelerine olumlu bir katkısı olduğu yorumu yapılabilir.

\section{Sonuç ve Tartışma}

ÖAY etkinliklerinin İngilizce dersinde kullanılması öğrencilerin derse karşı olan güdülerini olumlu bir biçimde etkilemektedir. Literatürde yer alan ÖAY ve güdülenmeyle ilgili bazı araştırmaların (Iran-Nejad, Watts, Venugopalan, Xu, 2006; Iran-Nejad ve Stewart, 2011; Morozov, 2011; Allan ve Driscoll, 2014; Lang, 2018a; 2018b; Tate ve Warschauer, 2018; Qian, 2019; Wright, Hodges, Zimmer ve McTigue, 2019) sonuçları bu sonuçla benzerlik göstermektedir. Bununla birlikte öğrenme ve güdü üzerine yapılan araştırmalara göre öğrenmeye dönük güdülenmeyi etkileyen tek bir faktörden söz etmenin mümkün değildir. Harrington ve Zakrajsek (2017) öğretilen kavramların anlamlandırılması ve kavramlarla özdeşleştirilmesinin öğrencilerin içeriği öğrenmeleri için gerekli olan güdüyü yükselttiğini belirtmişlerdir. Öğrencilerin yeni kavramları gerçek dünyayla birlikte anlamlandırmalarının onların onları zihinlerinde daha fazla tutmalarına yardımcı olduğunu ve bunun güdüyü artırmak için en önemli etmenlerden biri olduğunu ifade etmişlerdir. Bunun sebebinin ise güdülenmiş öğrencilerin dikkatlerini daha fazla ve uzun bir biçimde derse vermeye ve öğrenmek için daha fazla çaba sarf etmeye hazır olduklarından kaynaklandığını öne sürmüşlerdir. Bu ifadeler yapılan bu araştırmayı desteklemektedir.

Araştırma kapsamında ortaya çıkan bir diğer sonuç sınav kaygısıyla ilgilidir. Ön testlere göre DG2 lehine olan sonuç son testlere göre DG1 ile KG arasında KG lehine olmuştur. Bu durum DG2'ye uygulanan deneysel yöntemin sınav kaygısını azaltmada başarılı olduğu fakat DG1'e uygulanan deneysel yöntemin başarısız olduğu şeklinde yorumlanabilir. Bu farklılı̆ın "dönüt"ün sınav kaygısını azaltmadaki etkisinden kaynaklandığı ifade edilebilir fakat bu farklılık istatistikî olarak bir anlamlılık ifade etmemektedir.

Kaygı kelimesi her ne kadar olumsuz bir anlamda kullanılsa da her zaman olumsuz bir sonuca sebep olmaz. Aslında hiç kaygı duymamak dil öğrenimi açısından pek tercih edilen bir durum değildir. Aşırı kaygı ise öğrencilerin başarısız olmalarına sebep olmaktadır. Aşırı kaygı yüzünden sınava girmeden sınıfın kapısında dönen öğrenciler bulunmaktadır ve bu öğrenciler sınava girmedikleri için yabancı dil dersinden başarısız sayılmaktadırlar. Bu tür öğrencilere sınav kaygısı duygusuyla başa çıkmak için teknikler öğretilmesi gerekmektedir (Bekleyen, 2015). Sınav kaygısının sınıf içerisinde dil öğretimini nasıl etkilediğiyle ilgili yapılan çalışmalardan ortaya çıkan sonuçlar üç farklı şekilde ifade edilebilir (Ellis, 2008):

- Kaygı dil öğrenimi için faydalıdır.

- Kaygının dil öğrenimi üzerinde olumsuz bir etkisi vardır.

- Kaygı dil öğrenimiyle ilgili güçlüklerin nedeni değil sonucudur.

Akademik çalışmalarda elde edilen bu üç sonuca bakıldığında; kaygıyla ilgili ilk tespitin olumlu, ikinci sıradaki tespitin olumsuz olduğu, üçüncü tespitin ise neden değil sonuç olduğu görülmektedir. Akademik değerlendirme olan sınavla ilgili kaygı, yabancı dil kaygısının bileşenlerinden biridir. Bununla birlikte kaygının sebep ya da sonuç olduğuna dair araştırmacılar arasında bir uzlaşma bulunmamaktadır. Bu araştırmada elde sonuç güdülenme stratejileri bakamından daha başarılı olan öğrencilerin sınav kaygılarının yüksek olduğu yönündedir. Tespit edilen bu durum mükemmeliyetçi sınıflarda sıkça rastlanan bir durumdur. Mükemmeliyetçi ifadesinden kasıt başarı seviyesini hep en üstte tutma endişesi taşıyan öğrencilerin ya da öğretmenlerin bulunduğu öğretim öğrenme ortamıdır (Walsh ve UgumbaAgwunobi, 2002). Bu tür sınıflarda bulunan öğrenciler diğer arkadaşlarını da etkileyebilmektedirler. Bu durumu etkileyen bir değer etken de öğretmen tutumudur. Bununla birlikte sınav kaygısı; sınav yapılan ortamın fiziki koşulları, ders yükü, önceki sınavların kaygıları, cinsiyet, sınav gözetmeni, sınav süresi, sınav günü diğer sınavların olup olmaması gibi değişkenler tarafından etkilenebilmektedir. Dolayısıyla sınav kaygısı kontrolü zor bir güdü stratejisidir ve değişkenler etki değerlerine göre tanımlanarak kontrol altına alınmadığı sürece Türkiye'de İngilizce öğrenen öğrenciler için azaltılması zor bir kaygı çeşididir. Sınav kaygısıyla başa çıkmak için tavsiye edilen yöntemler arasında olumlu düşünme teknikleri öğrenmek, kaygı oluşturan durumları/sebepleri listelemek ve tedbirleri tartışmak, kaygı ile başa 
çıkıldığında bu davranışı ödüllendirmek, sınav sonrasındaki duyguları analiz etmek vb.dir (Oxford, 2002). BU tedbirleri gerçekleştirmek için ÖAY etkinlikleri bir araç olarak kullanılabilir. Öncelikle sınav kaygısının sebeplerini ortaya çıkarmak için daha sonra tespit edilen nedenlere göre farklı etkinlik tasarlamak ya da yine ÖAY etkinliği kullanarak öğrencilere bu konuda dönüt vermek için kullanılabilir.

Güdünün öğrenciyi başarıya götüren önemli bir faktör olduğu (Gottfried, 1985; Pintrich ve De Groot, 1990; Zimmerman ve Pons, 1990; Acat ve Köşgeroğlu, 2006; Livingston, 2017; Dörnyei, 2019; Hart, 2019; Özhan ve Kocadere, 2020; Stupnisky, Hall ve Pekrun, 2019) düşünüldüğünde ÖAY etkinliklerinin öğrenciyi başarıya götüren önemli bir etkinlik türü olduğu ifade edilebilir. Güdülenmeyi etkileyen diğer faktörle birlikte uyum içerisinde kullanıldığında ÖAY etkinlikleri İngilizce dersinde öğrencilerin güdülenmesini sağlamada etkili bir araç olduğu sonucuna ulaşılmıştır.

\section{Öneriler}

\section{Öğretmenlere Yönelik Öneriler}

Öğretmenler,

- ÖAY etkinliklerini kullanarak öğrencilerin hatalarını sınavlardan önce tespit edebilirler.

- Tespit edilen hatalara yönelik dönütleri ÖAY ile öğrencilere iletebilirler.

- ÖAY etkinliklerini kullanarak öğrencilerin hatalarını düzeltip düzeltmediklerini gözlemleyebilirler.

- ÖAY etkinlikleriyle öğrencilerini derse karşı güdüleyebilirler.

\section{Araştırmacılara Yönelik Öneriler}

Araştırmacılar,

- Yabancı dil seviyesi daha yüksek olan öğrencilerle etkinliğin tamamının hedef yabancı dilde yapıldığı araştırmalar yapabilir.

- Farklı eğitim kademelerinde ÖAY etkinliklerinin etkileri üzerinde araştırma yapabilirler.

Yapılan bu çalışmada "Yükseköğretim Kurumları Bilimsel Araştırma ve Yayın Etiği Yönergesi" kapsamında uyulması belirtilen tüm kurallara uyulmuştur. Yönergenin ikinci bölümü olan "Bilimsel Araştırma ve Yayın Etiğine Aykırı Eylemler" başlığı altında belirtilen eylemlerden hiçbiri gerçekleştirilmemiştir.

\section{References}

Acat, M. B., \& Köşgeroğlu, N. (2006). Güdülenme kaynakları ve sorunları ölçeği. Anadolu Psikiyatri Dergisi, 7(4), 204-10.

Aliş, E. (2008). Yıldız Teknik Üniversitesi Yabancı Diller Yüksek Okulu Temel Ingilizce Bölümü öğretim elemanlarının mesleki deneyimlerinin ve ingilizce öz yeterlik inançlarının iletişimsel dil öğretimine karşı tutumlarına etkisi. Yayımlanmamış Yüksek Lisans Tezi. İstanbul: Yıldız Teknik Üniversitesi.

Allan, E. G., \& Driscoll, D. L. (2014). The three-fold benefit of reflective writing: Improving program assessment, student learning, and faculty professional development. Assessing Writing, 21, 37-55.

Bekleyen, N. (2015). Dil Öğrenmede Etkili Olan Bireysel Farklılıklar. İ̧̧inde Bekleyen, N. (Ed.) Dil Öğretimi. (448-455). Ankara: Pegem Akademi.

Büyüköztürk, Ş., Akgün, Ö. E., Kahveci, Ö. ve Demirel, F. (2004). Güdülenme ve öğrenme stratejileri ölçeğinin Türkçe formunun geçerlik ve güvenirlik çalışması. Kuram ve Uygulamada Eğitim Bilimleri, $4(2), 207-239$. 
iNCIRCi \& VARDAR- Çukurova Üniversitesi Eğitim Fakültesi Dergisi, 50(2), 2021, 877-906

Cameron, J. (2001). Negative effects of reward on intrinsic motivation-A limited phenomenon: Comment on Deci, Koestner, and Ryan. Review of Educational Research, 71(1), 29-42.

Cardelle, M. ve Corno, L. (1981). Effects on second language learning of variations in written feedback on homework assignments. Tesol Quarterly, 15(3), 251-261.

Cohen, P. A. (1980). Effectiveness of student-rating feedback for improving college instruction: A metaanalysis of findings. Research in higher education, 13(4), 321-341.

Comission of Europe (CoE). (2001). Common European framework of reference for languages: Learning, teaching, assessment. Cambridge: Cambridge University Press.

Çalışkan, N. ve Çangal, Ö. (2013). Yabancılara Türkçe öğretiminde dil ihtiyaç analizi: Bosna-Hersek örneği. Abant İzet Baysal Üniversitesi Eğitim Fakültesi Dergisi, 13(2), 310-334.

Dörnyei, Z. (2019). Task motivation. Researching L2 task performance and pedagogy: In honour of Peter Skehan, 13, 53.

Ellis, R. (2008). 31 Explicit Form-Focused Instruction and Second Language Acquisition. The handbook of educational linguistics, 437.

Gottfried, A. E. (1985). Academic intrinsic motivation in elementary and junior high school students. Journal of educational psychology, 77(6), 631.

Güneş, F. (2011). Dil Öğretim Yaklaşımları ve Türkçe Öğretimindeki Uygulamalar/Language Teachıng Approaches And Theır Applıcatıons In Teachıng Turkısh. Mustafa Kemal Üniversitesi Sosyal Bilimler Enstitüsü Dergisi, 8(15), 123-148.

Harrington, C. ve Zakrajsek, T. D. (2017). Dynamic lecturing: Research-based strategies to enhance lecture effectiveness. Stylus Publishing, LLC.

Hart, C. (2019). Controlled Burn: A Story of Growth. Educational Leadership, 76(8), 28-33.

Hochberg, Y. ve Tamhane, A. C. (1987). Multiple comparison procedures. New Jersey: John Wiley ve Sons, Inc.

Iran-Nejad, A. ve Stewart, W. (2011). Understanding knowing and its relation to understanding. In American Institute of Higher Education 6th International Conference Proceedings, 4, 190.

Iran-Nejad, A., Watts, J., B., Venugopalan, G., Xu, Y. (2006). The Wholetheme Window of Dynamic Motivation in Writing to Learn Critical Thinking: A Multiple-Source Perspective. Writing and motivation, 31.

Kasanga, L. A. (1996). Peer Interaction and L2 Learning. Canadian Modern Language Review, 52(4), 61139.

Kayri, M. (2009). Araştirmalarda gruplar arasi farkin belirlenmesine yönelik çoklu karşilaştirma (post-hoc) teknikleri. Journal of Social Science, 55.

Kepner, C. G. (1991). An experiment in the relationship of types of written feedback to the development of second-language writing skills. The modern language journal, 75(3), 305-313.

Lang, G. (2018a). Using Learning Journals to Increase Metacognition, Motivation, and Learning in Computer Information Systems Education. Information Systems Education Journal, 16(6), 39-47.

Lang, G. (2018b). Can Learning Journals Increase Metacognition, Motivation, and Learning? Results from a Randomized Controlled Trial in a Computer Information Systems Course. Information Systems Education Journal, 16(6), 39.

Lasagabaster, D., Doiz, A. ve Sierra, J. M. (Eds.). (2014). Motivation and foreign language learning: From theory to practice, 40 . John Benjamins Publishing Company.

Livingston, S. (2017). Motivation and student success in developmental education ( 10287174). https://search.proquest.com/docview/1935579801?accountid=142289 $\quad 25.10 .2019 \quad$ tarihinde erişilmiştir. 
MEB, (2018a). Ortaöğretim Ingilizce Dersi 9, 10, 11, ve 12. sınıflar Öğretim Programı, http://mufredat.meb.gov.tr/ProgramDetay.aspx?PID=342 13.11.2019 tarihinde erişilmiştir.

Morozov, A. (2011). Student attitudes toward the assessment criteria in writing-intensive college courses. Assessing Writing, 16(1), 6-31.

Oxford, R. L. (2002). Language learning strategies in a nutshell: Update and ESL suggestions. Methodology in language teaching: An anthology of current practice, 4(3), 124-132.

Özhan, Ş. Ç., \& Kocadere, S. A. (2020). The effects of flow, emotional engagement, and motivation on success in a gamified online learning environment. Journal of Educational Computing Research, 57(8), 2006-2031.

Paker, T. (2012). Türkiyeâ de Neden Yabancı Dil (İngilizce) Öğretemiyoruz ve Neden Öğrencilerimiz İletişim Kurabilecek Düzeyde İngilizce Öğrenemiyor? Pamukkale Üniversitesi Eğitim Fakültesi Dergisi, 32(32), 89-94.

Philp, J., Adams, R. ve Iwashita, N. (2013). Peer interaction and second language learning. London: Routledge.

Philp, J., Walter, S. ve Basturkmen, H. (2010). Peer interaction in the foreign language classroom: what factors foster a focus on form?. Language Awareness, 19(4), 261-279.

Pintrich, P. R. ve De Groot, E. V. (1990). Motivational and self-regulated learning components of classroom academic performance. Journal of educational psychology, 82(1), 33.

Qian, Y. (2019). Motivation to English Academic Writing: Chinese Students' Literacy Autobiography. Theory and Practice in Language Studies, 9(5), 530-536.

Saville, D. J. (1990). Multiple comparison procedures: the practical solution. The American Statistician, 44(2), 174-180.

Seçkin, H. (2011). Illköğretim 4. sınıf İngilizce dersi öğretim programına ilişkin öğretmen görüşleri. Uluslararası Insan Bilimleri Dergisi, 8(2), 550-577.

Stupnisky, R. H., Hall, N. C. ve Pekrun, R. (2019). The Emotions of Pretenure Faculty: Implications for Teaching and Research Success. The Review of Higher Education, 42(4), 1489-1526.

Tate, T. P. ve Warschauer, M. (2018). Going Beyond "That was fun": Measuring Writing Motivation. Journal of Writing Analytics, 2, 257-279.

Terrell, T. D. (1977). A Natural Approach to Second Language Acquisition and Learning 1. The modern language journal, 61(7), 325-337.

Tuan, H. L., Chin, C. C. ve Shieh, S. H. (2005). The development of a questionnaire to measure students' motivation towards science learning. International Journal of Science Education, 27(6), 639-654.

Walsh, J. J., ve Ugumba-Agwunobi, G. (2002). Individual differences in statistics anxiety: The roles of perfectionism, procrastination and trait anxiety. Personality and Individual Differences, 33(2), 239251.

Williams, L. J., ve Abdi, H. (2010). Fisher's least significant difference (LSD) test. Encyclopedia of research design, 218, 840-853.

Wright, K. L., Hodges, T. S., Zimmer, W. K., \& McTigue, E. M. (2019). Writing-to-learn in secondary science classes: For whom is it effective?. Reading \& Writing Quarterly, 35(4), 289-304.

Young, T., Hazarika, D., Poria, S. ve Cambria, E. (2018). Recent trends in deep learning based natural language processing. IEEE Computational intelligence magazine, 13(3), 55-75.

Zimmerman, B. J. ve Martinez-Pons, M. (1990). Student differences in self-regulated learning: Relating grade, sex, and giftedness to self-efficacy and strategy use. Journal of educational Psychology, 82(1), 51. 